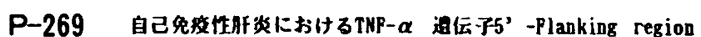
Opolynorphis:

四山大学 医学部第一内枓

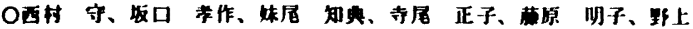

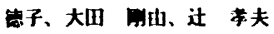

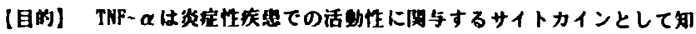

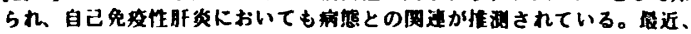
WW- $\alpha$ 道伝-35' -Flanking regionのposition-1031,-863,-857,-308, -

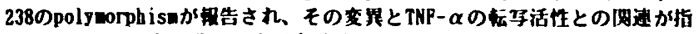

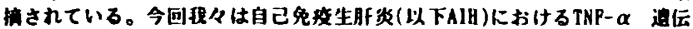

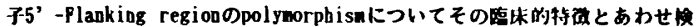

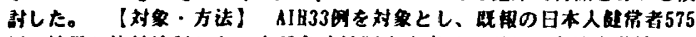

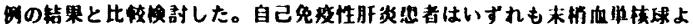

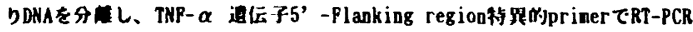
を行い、PCR库物のdirect sequenceによりpolymorphismを决定した。

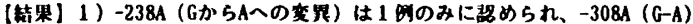
は现められなかった。 2) -1031C (T-C)、-863A (C-A)、-857T (C-T)の Allele颀度はAIHでそれそれ7.6\%、10.6\%、27.3\%であり、コントロール (16.0\%、14.0\%、17.7\%)に比较して、-857Tの颣度がかった。2) -

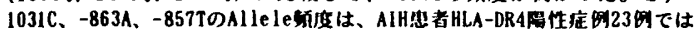

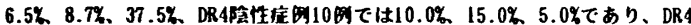

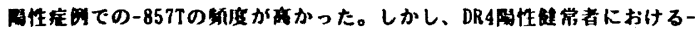
857TのAllele類度は25.0\%であり、AIH出者における-857Tの高後度はHLA-

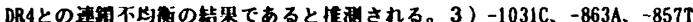

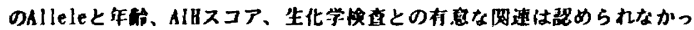
た。【搭踰】AlHにおけるTNP- $\alpha$ 进伝子5' - Planking regionの-1031C, -

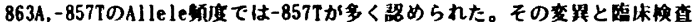
持果との闌には有息な圆速は見られなかった。

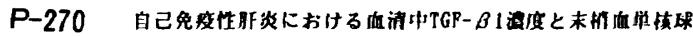
でのTG- $\beta$ receptor type IIの叒现レヘル

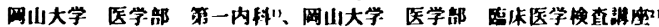

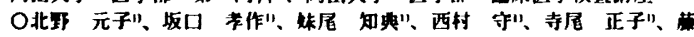

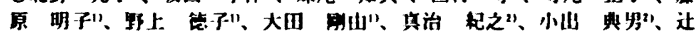
孝夫"

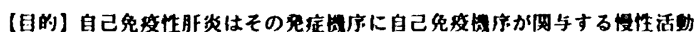

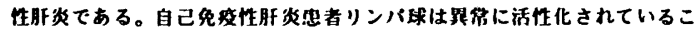

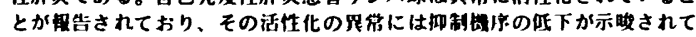

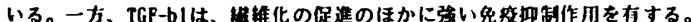

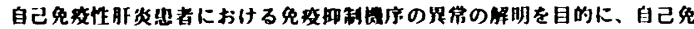

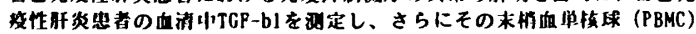

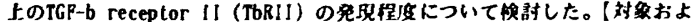

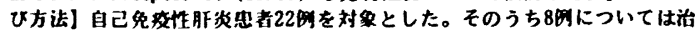

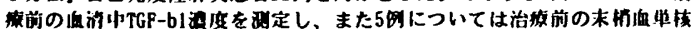

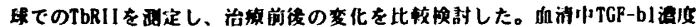

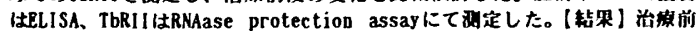

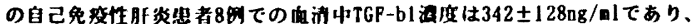

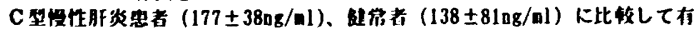

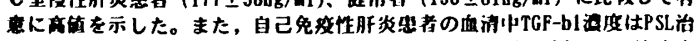

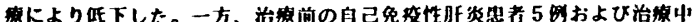

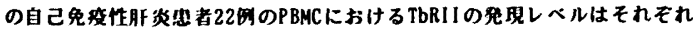

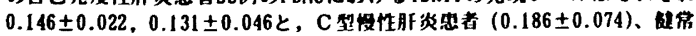

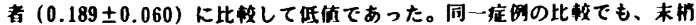

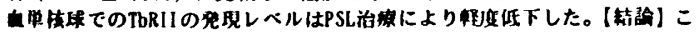

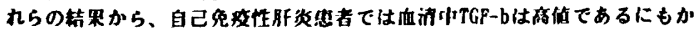

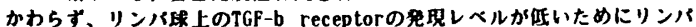

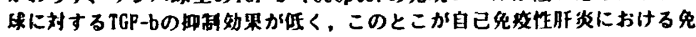

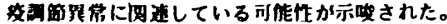

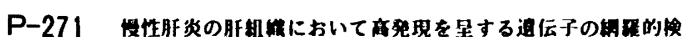

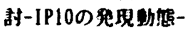

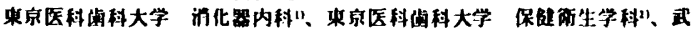

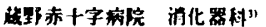

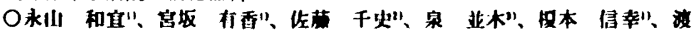
边 守”

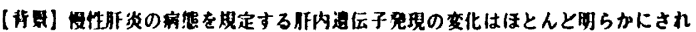

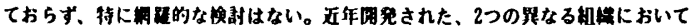

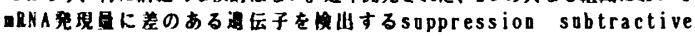

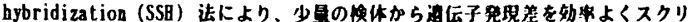

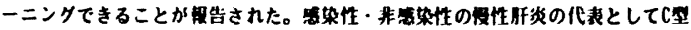

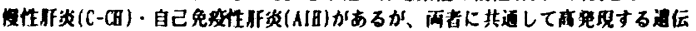
子か存在すれば乎炎のconon pathwayにおいて重要である可作性が示唆される。

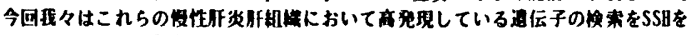

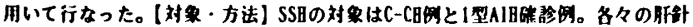

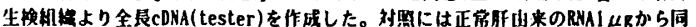

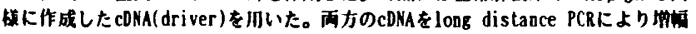

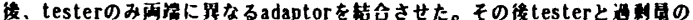

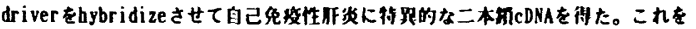

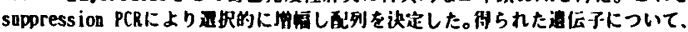

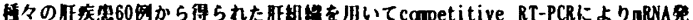

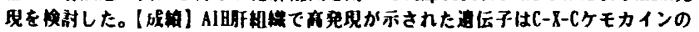
つであるIP(interferon $\gamma$-indacible protein)10とCD94であった。またC-CHAF梱

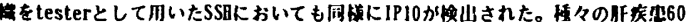

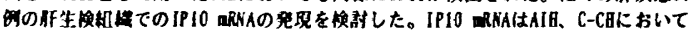

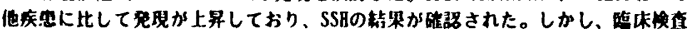

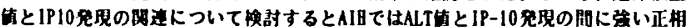
网を㷎めた(

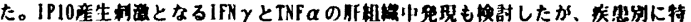

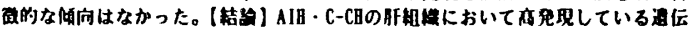

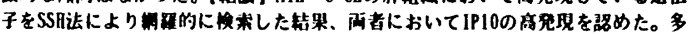

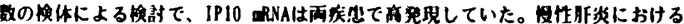

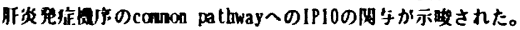

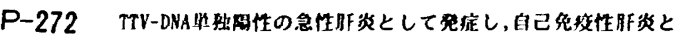 なった一闪 \\ 高郃民医速中央病院 内科

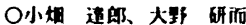

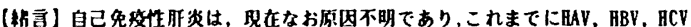

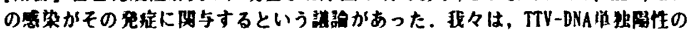

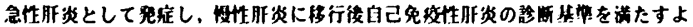

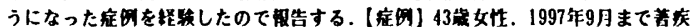

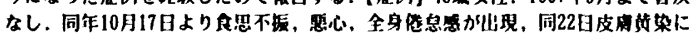

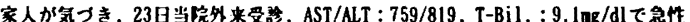

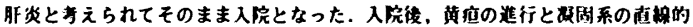

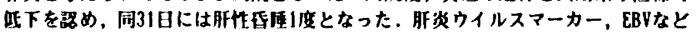
のウイルスマーカー, 自己抗休はいずれも附所見て, BGF-RNA, silent BBV-

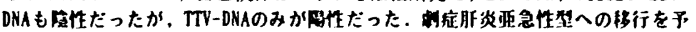

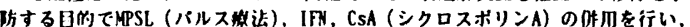

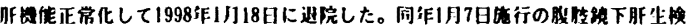

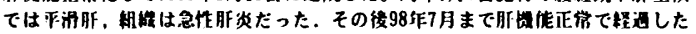

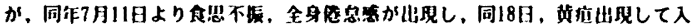

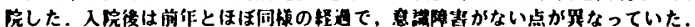
IDCA600ng + SNMC100n1の投与てALT: 100前能, T-Bil.<1.0ng/dlとなって迎院し

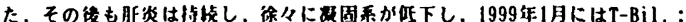

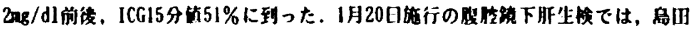

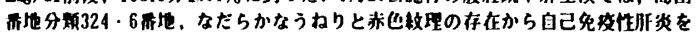

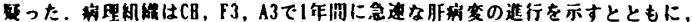

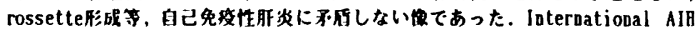

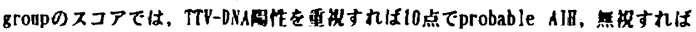
16点でdefinite AlHとなるため, 十分なインフォームドンセントのもとで99作

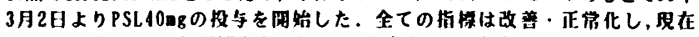

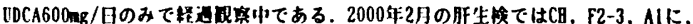

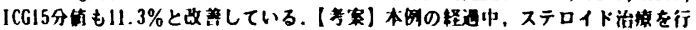

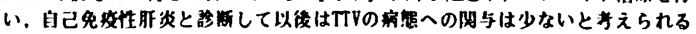

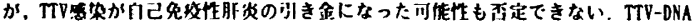

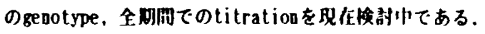




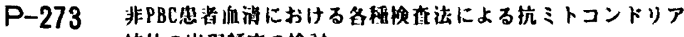 抗休の山谓颗度の悗討}

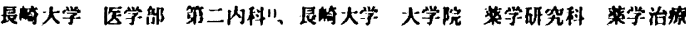

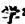

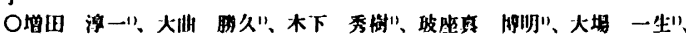

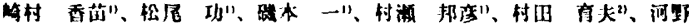
茷"

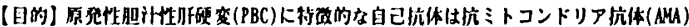

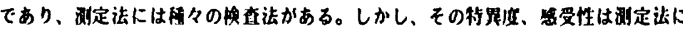

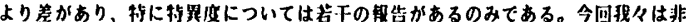

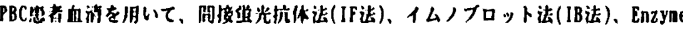

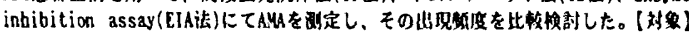

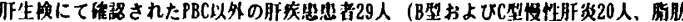

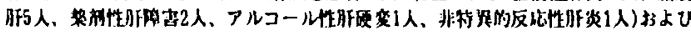

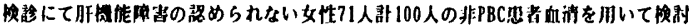

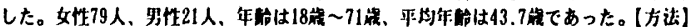

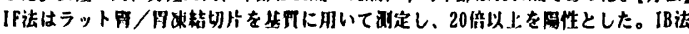

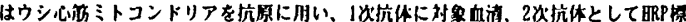

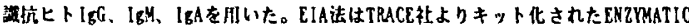

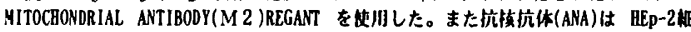

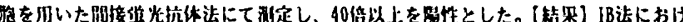

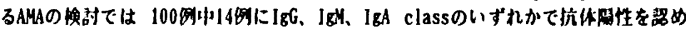

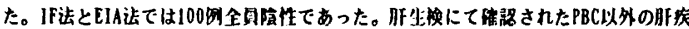

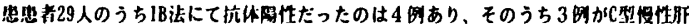

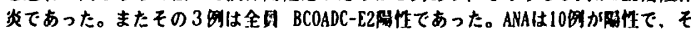

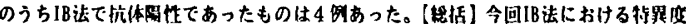

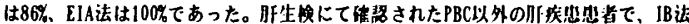

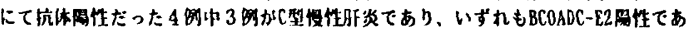

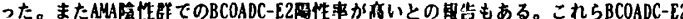

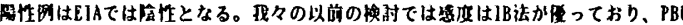

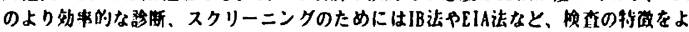
く理解した上で買抧していく必要があると考えられた。

\section{P-274 PBCにおけるM2抗体スクリーニンクとしての新しいELISA}

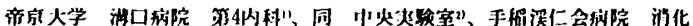
器病センターリ

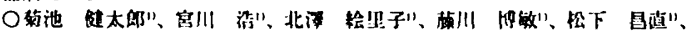

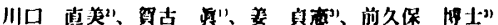

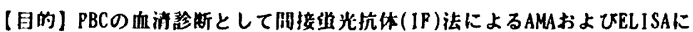

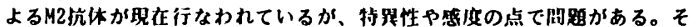
こで今回、M2沆体测定のための新たなELISA系を㜀羿した。本ELISAの特界

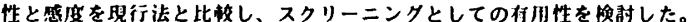

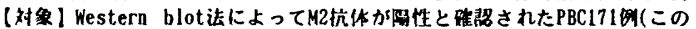

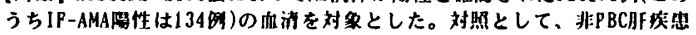

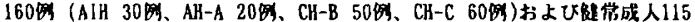
田の片消を用いた。(方法) 1)ELISAの作成：フタ心方ミトコンドリア分面 を抗原とした使川した。この蛋白をSDS-PAGEで展閂し、卡要M2の recombinant自向(PDC-E2, BCOADC-E2)によるinhibition testによって抗原

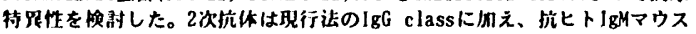

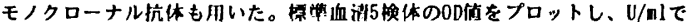
表示した。(成相) 1)抗原の特界性：抗原としたフ夕心放ミトコントリア分

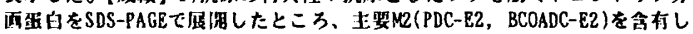
ていることか蚝虫された。さらにrecombinant PDC-E2、BCOADC-E2蛋目を前 処理したinhibition testによって睹积された。2) cut of $f$ indexの設定：

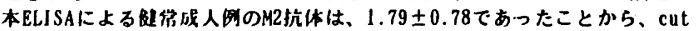

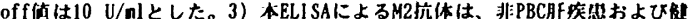
常成人では全甽除性であった。4) 本ELISAによるM2抗作は、PBC171间小133

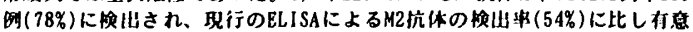

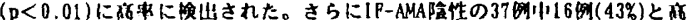

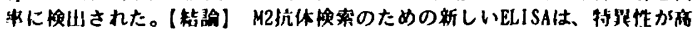
く、現行法を上回る思度を右することから、PBCのM2挆体スクリーニンク法 としての棈めて们川である。

\section{P-275 PBCにおけるPDC-E2杭体とBCOADC-E2抗作の界析

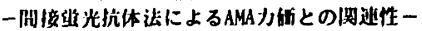

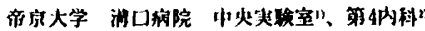

O川口 直美"、安川 浩"

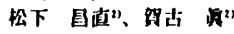

【目的】 PBC血激中のM2抗体成分を分析するため、PDC-E2抗休とBCOADC-E2抗

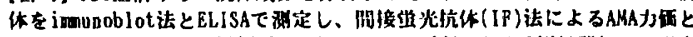

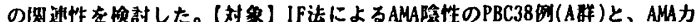

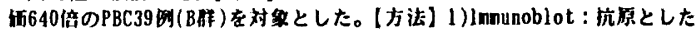

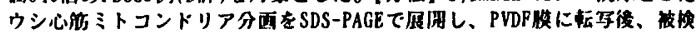
血消と反庶させた。胎山された主要band $(74,50 \mathrm{kDa})$ はinhibition testr

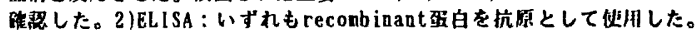

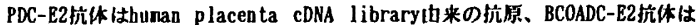
牫々が品作したKB cell lines山来の抗原を图相したRLISAで各々测定した。

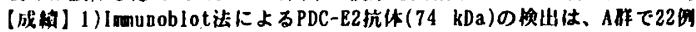

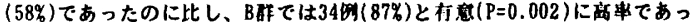

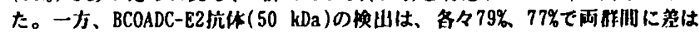

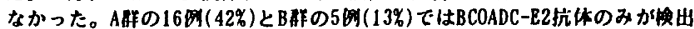

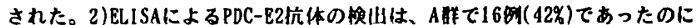

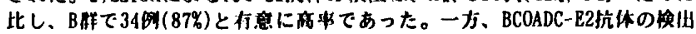

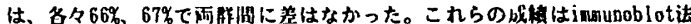
と同栚の阿向であった。また、A陆ではPDC-E2、BCOADC-E2抗休のOD估は有

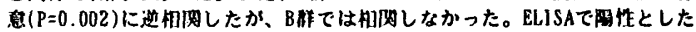

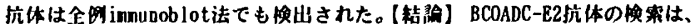

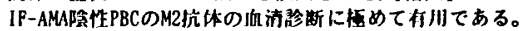

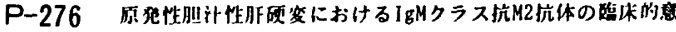 积}

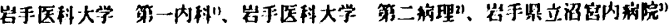

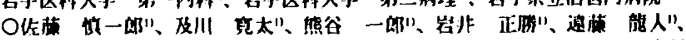

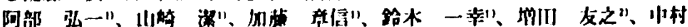
篗志”

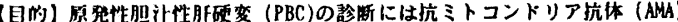
とともにIgGクラス抗M2抗体の渭定が头く用いられている。最近、IgMクラ

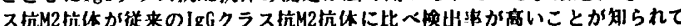
いる。今回、我々はPBC国についてIgMクラス抗M2抗作を测定し、本抗休の

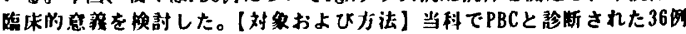

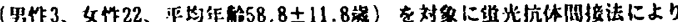
AMA、ELIZA法によりIgGクラス抗M2抗休（IgG-M2）、IgMクラス抗M2抗休

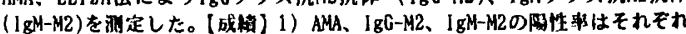
$80.6 \%(29 / 36) 、 72.2 \%(26 / 36) 、 91.7 \%$ (33/36)であった。AMA䧔性 7田 (いずれもIgG-M2䧔性)のうち4网でIgM-M2が四性であうた $(57.1 \%)$ IgG-

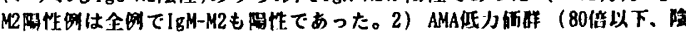
性测含む）11判ではIgG-M2は28.6\% (4/14)、IgM-M2は78.6\% (11/14)に

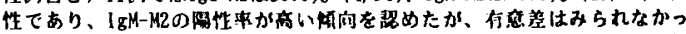

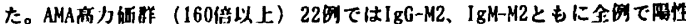
であった。3) AMA、IgG-M2、IgM-M2の㭥出パターンからAMA(+)IgG

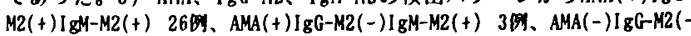

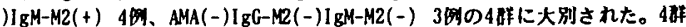

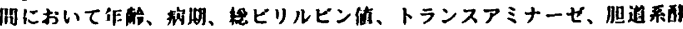

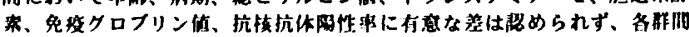

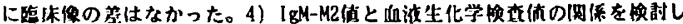

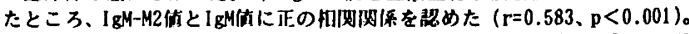

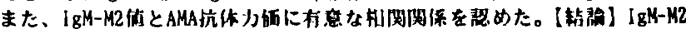
はAMA、IgG-M2に比へ司性事がく

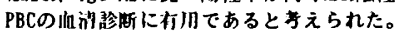




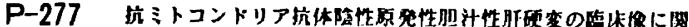
する塔封

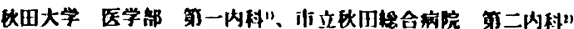

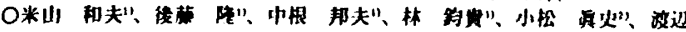
地”

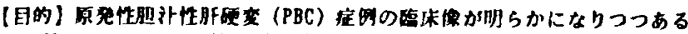

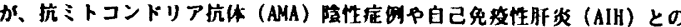

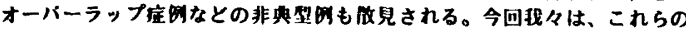

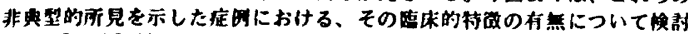

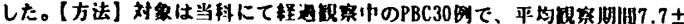

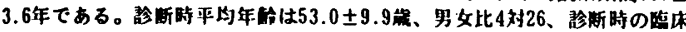

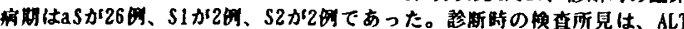
$75.3 \pm 56.1 \mathrm{U} / \mathrm{l}$ 、ALP $514.9 \pm 484.4 \mathrm{U} / \mathrm{l} 、 \mathrm{~T}-\mathrm{Bil} \quad 0.92 \pm 0.72 \mathrm{ng} / \mathrm{dl} 、 \gamma$-GTP $228.6 \pm 169.1 \mathrm{~V} / \mathrm{l}$ 、IgM $441.3 \pm 280.0 \mathrm{ng} / \mathrm{dl}$ 、 $\operatorname{lgG} 1778.0 \pm 630.8 \mathrm{ng} / \mathrm{dl}$ であ

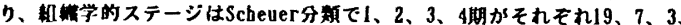

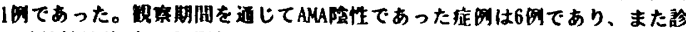

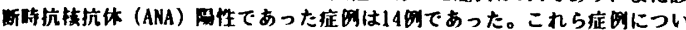

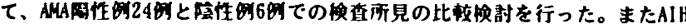

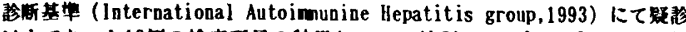

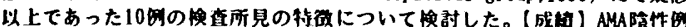

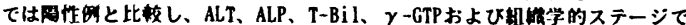

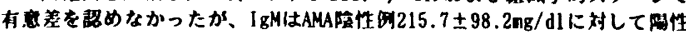

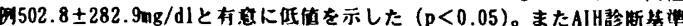

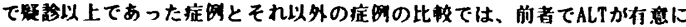

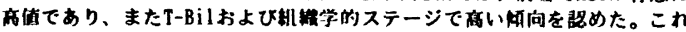

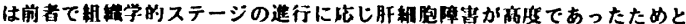
考えられた。さらにこの中で1986年にChazouilleresらの提唯したPBC-AIH

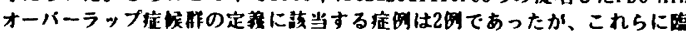

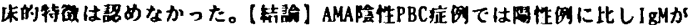
标息に听估であった。

\section{P-278 原発性胆计性胙硬案出者におけるMannose-Binding Lectin (MB L) 通伝子の解所}

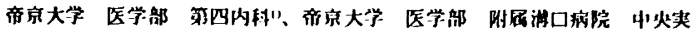

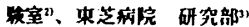

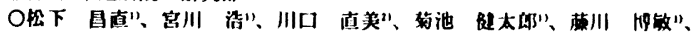

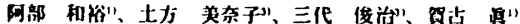

(钴草) Mannose-Bioding Lectin (MB L) は先天性免疫の重要な一因子で

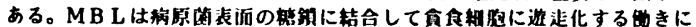
则えて、矛三の林休程路であるレクチン柽路の活性化に圆わっている。以

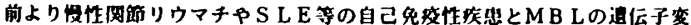

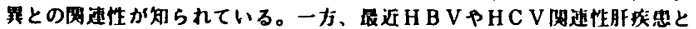

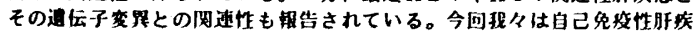

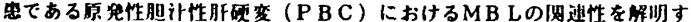

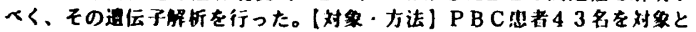

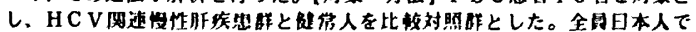
ある。既艮のR F L P 法と S S P-PCR (allele-specific PCR) 法を用

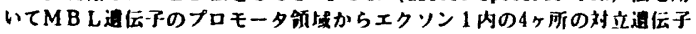

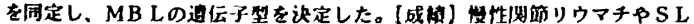

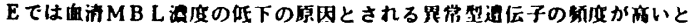

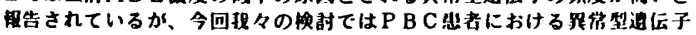

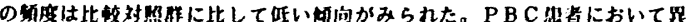

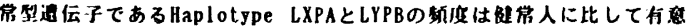

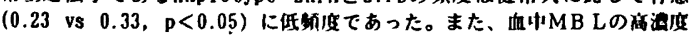
を来すHaplotspe HYPAの够安は处常人に比して有息 $(0.53$ vs $0.44, p<$

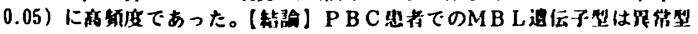

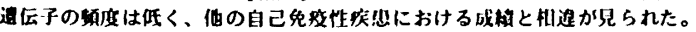

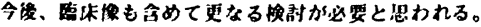

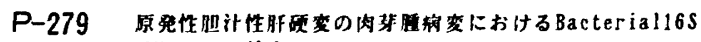
rRNA geneの惨山

金沢大学 医学部 第二病理

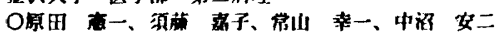

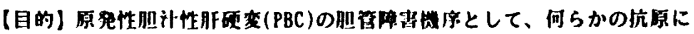

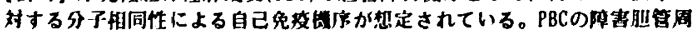

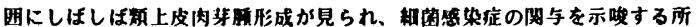
見と考えら九る。今回、我々は、PBCの肉芽脸性病变部から租图道伝子の分

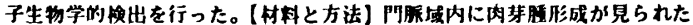

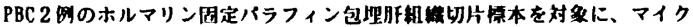

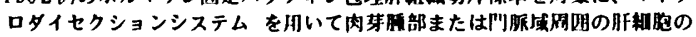
みを通択的に保取した。また、刘照として原齐性硬化性胆管炎(PSC) 1 月の

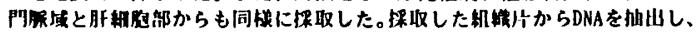

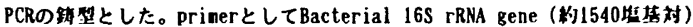
内に 10 力所存在する conversed regionから1400Por, 1540Rev(PCR座物的

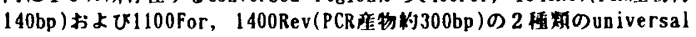
priner 対を用いた。そのPCR産物を subcloning後、10倜跬度のコロニーから

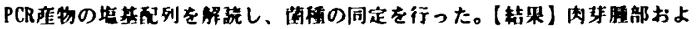

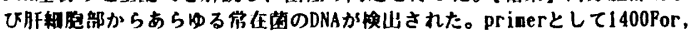
1540Revを用いた堨合、Lactobacillus, Pseudononas，Streptococcus属落

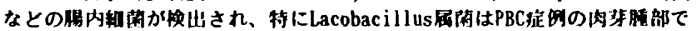

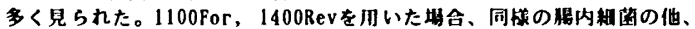
Propionibacteriun acnes (16S rRNA艮が1480峌基对であり、1540Revの

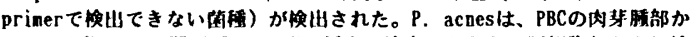

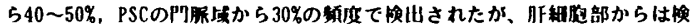

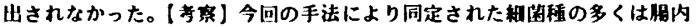

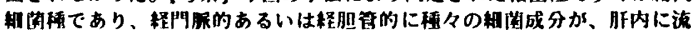

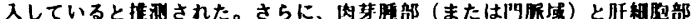

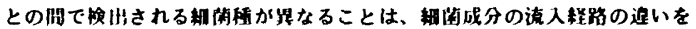
反吷しているのかもしれない。また、P. acnesは、近作、サルコイトーシ

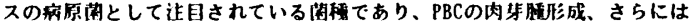
PBCの的照形成に阅わっている可能性が示哓された。

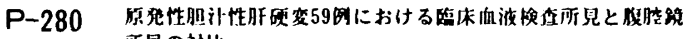
所見の対比

米海大学亚学部 说化器内科 1

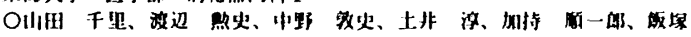

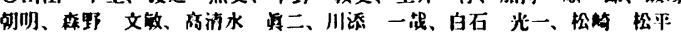

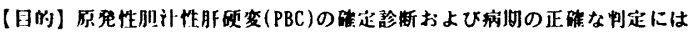

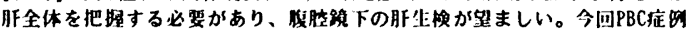

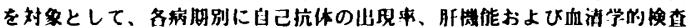

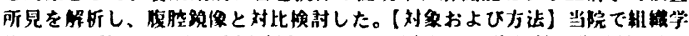

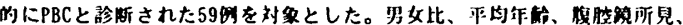

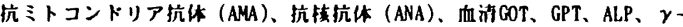

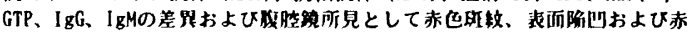

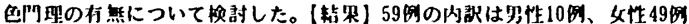

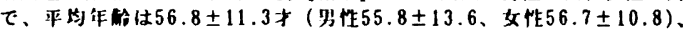

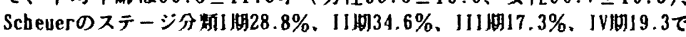

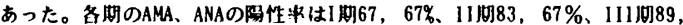
$33 \%$ 、IVIJ8 80，40\%であった。伯济ALPは上I/

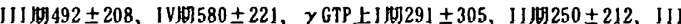

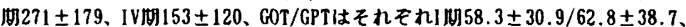

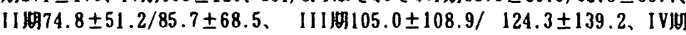

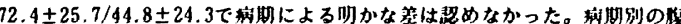

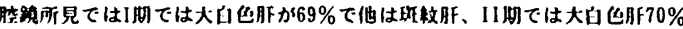

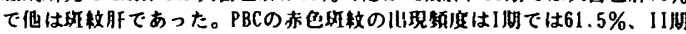

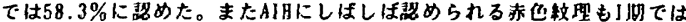
$18.2 \%$ 、1四では8.3\%に瑟められた。さらに赤色校理はAMA $(+) 、 A N A(+)$ PBCでは25\%に陆性で们るのに対しAMA(-)、ANA (t) PBCでは $40 \%$ に琶めら

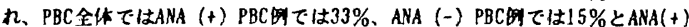

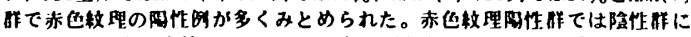

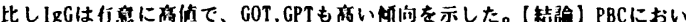

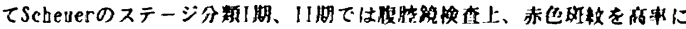

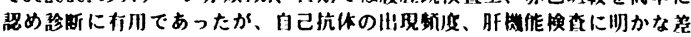

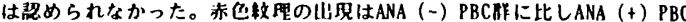

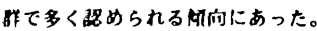




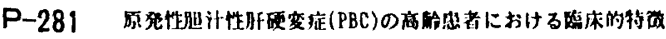

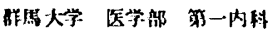

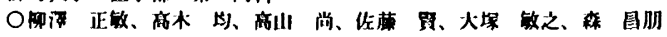

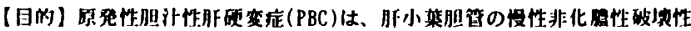

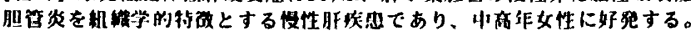

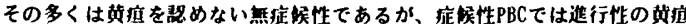

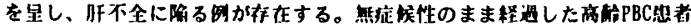

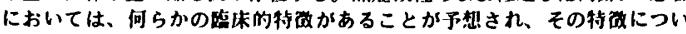

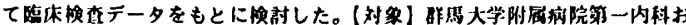

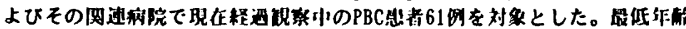

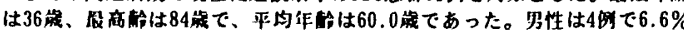

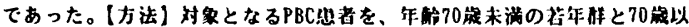

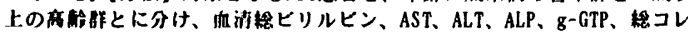
ステロールの6项目について、それぞのの平岛值との比数檚討を行った。

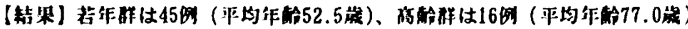

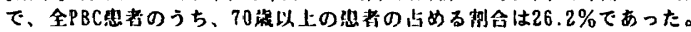

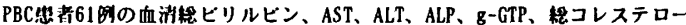
ルの平为湖は、それそれ、0.5 mg/dl、22.0IU/L、15.5IU/L、384.5 IU/L、

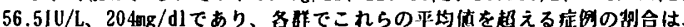

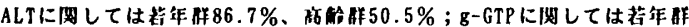

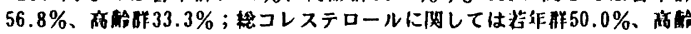

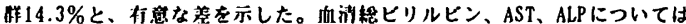

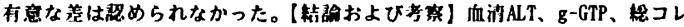

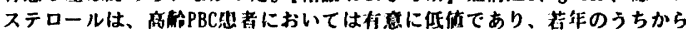

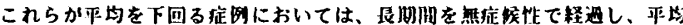
寿命を全うし得るものと考えられた。

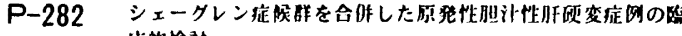

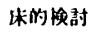

福帛望立医科大学 医学部 第二内科

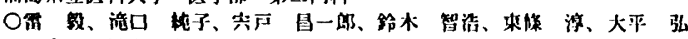

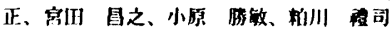

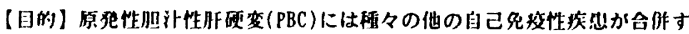
ることか知られており、本邦では20-60\%に合作する。なかでもェータレ

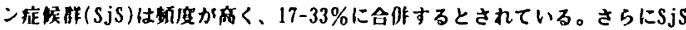

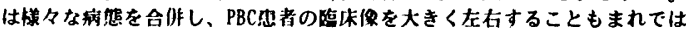

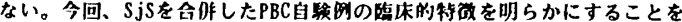

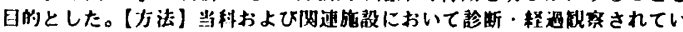

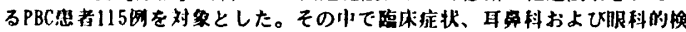

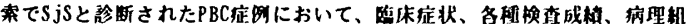

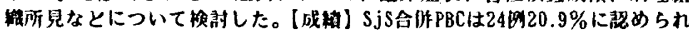

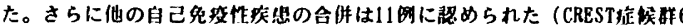

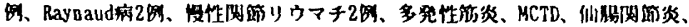

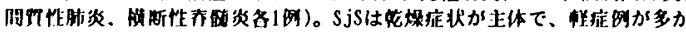

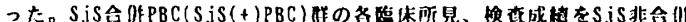

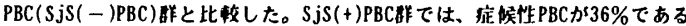

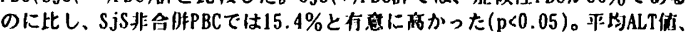

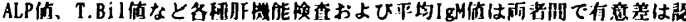
められなかった。平约IgC倠は、SjS(+)PBC で存意に高仿であった（2547士

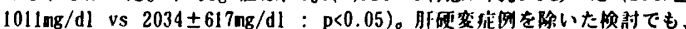

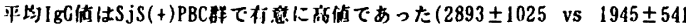

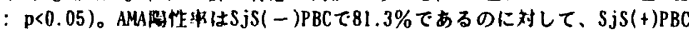

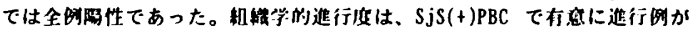
多かった。(Stage I, II , 111, IV；19\%,24\%,24\%,33\% vs $40 \%, 32 \%, 12 \%, 16 \%$ : $p<0.05$ ) (粘编】 SjS合(DFPBCはSjS非合作PBCに比し、

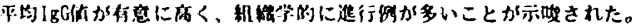

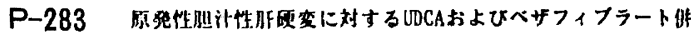

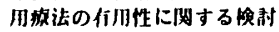 \\ 川峰医科大学 队科学 消化器1部叫

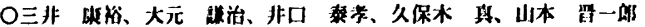

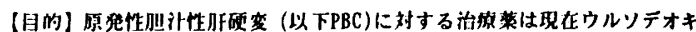

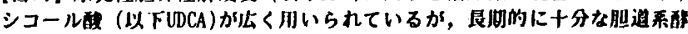

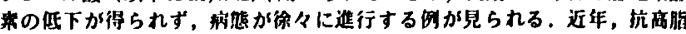

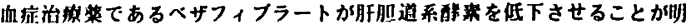

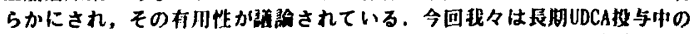

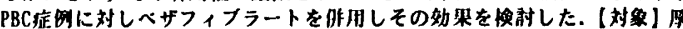

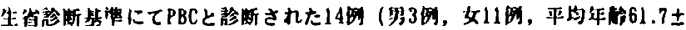
7.2 , asyntonatic;a-PBC:8 syntonatic;s1-PBC:5

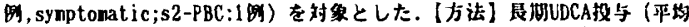

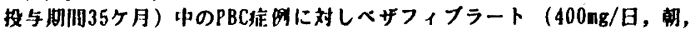

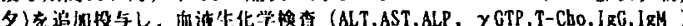

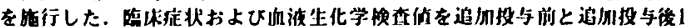

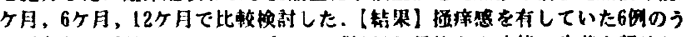

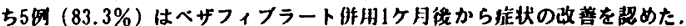
血波生化学㭥直ではべサフィフラート追加投与1ケ月绻にはALP, $\gamma$ GTP，T-

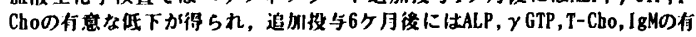

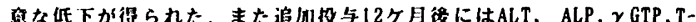

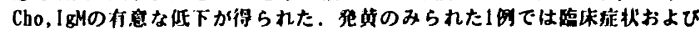

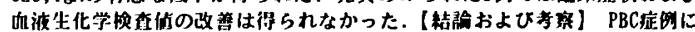

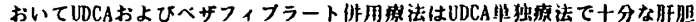

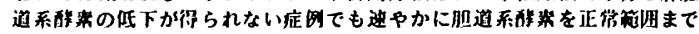
纸下させ，さらに畏䀛的にはALTをも低下させうる治旗法と考えられた。

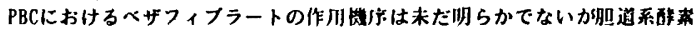

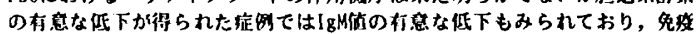

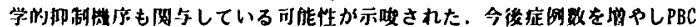

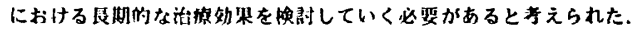

\author{
P-284原発性胆汁性朋硬変に対するUDCAおよびベサフィブラート作 \\ 投与奻果について \\ 千集大学医学部第一内枓

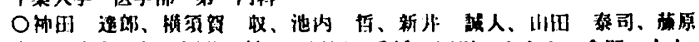

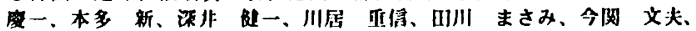 \\ 帨所 宏光
}

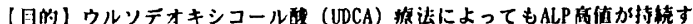

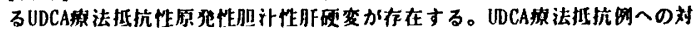

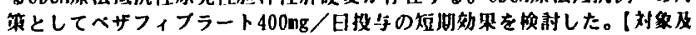

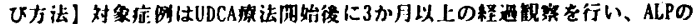

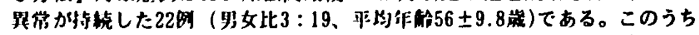

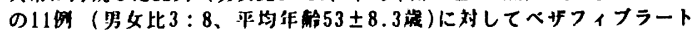

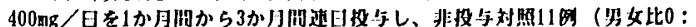

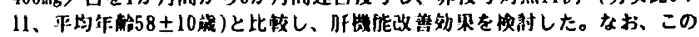

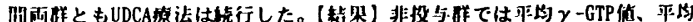

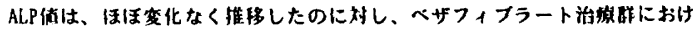

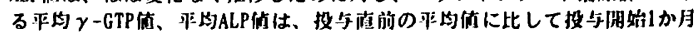

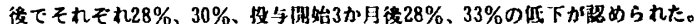

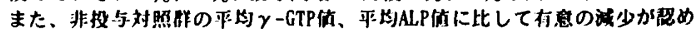

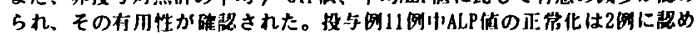

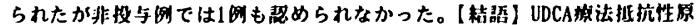
発性胆外性朋硬晏に对するベザフィフラート400mg/日投与により $\gamma$-GTP

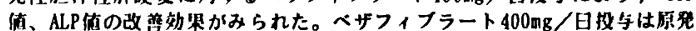

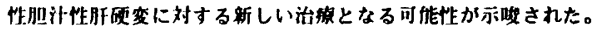




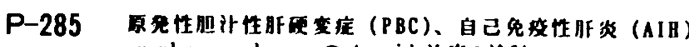
雪上需完

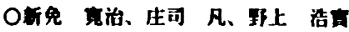

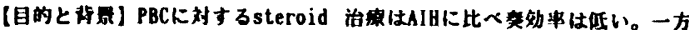

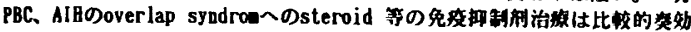
するとの银告かある。今回我々はPBC、AIIlのoverlap syndronに対し

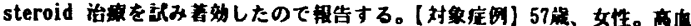

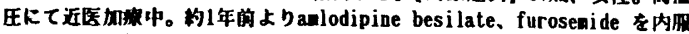

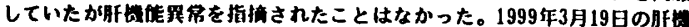

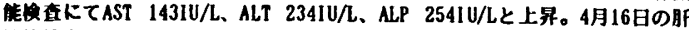

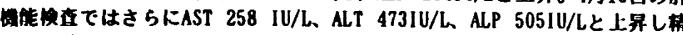

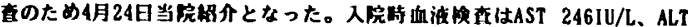
4421U/L、ALP 300IU/L、 $\gamma$-GTP $1331 \mathrm{U} / \mathrm{L} 、 \mathrm{~T}-\mathrm{Bi} 10.6 \mathrm{ng} / \mathrm{dl}$ 、

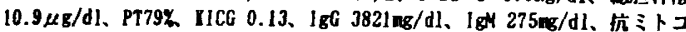

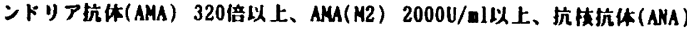

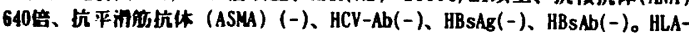

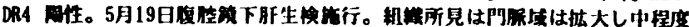

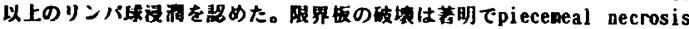

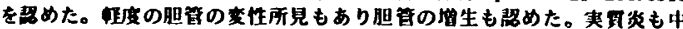

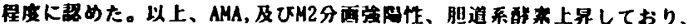

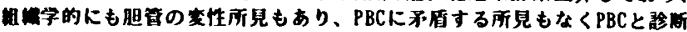

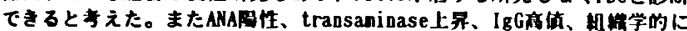

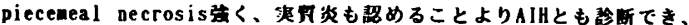

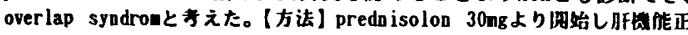

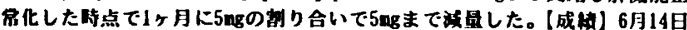

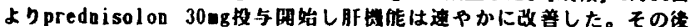
predoisolon 斩し1999年11月4日には5ngまで㨁したか、AST,ALTは正最

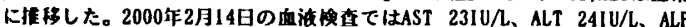
194IU/L、 $\gamma$-GTP 19IU/L、T-Bil $0.4 \mathrm{mg} / \mathrm{dl}$ 、YICG $0.28 、 \mathrm{IgG} 1562 \mathrm{mg} / \mathrm{dl}$ ह 正曾化していた。自己抗休はAMA320倍以上、ANA(-)であった。2000年3月3

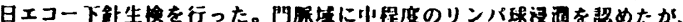

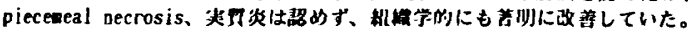

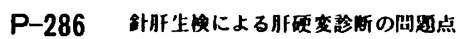

久留米大学 医学部窉理学放空

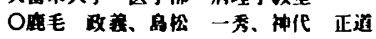

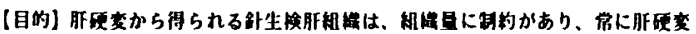

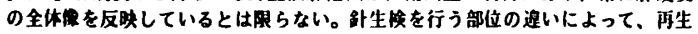

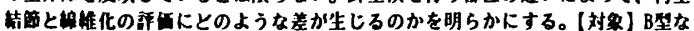

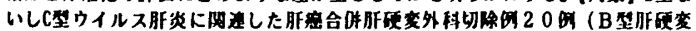

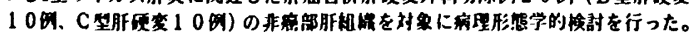

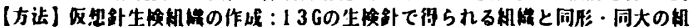

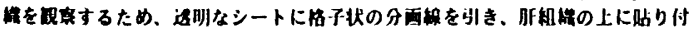

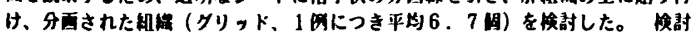

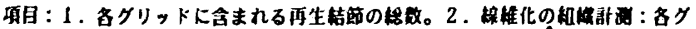

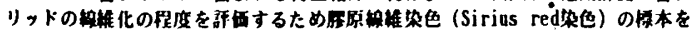

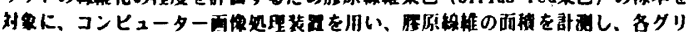

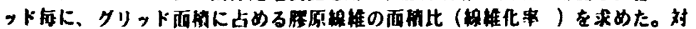

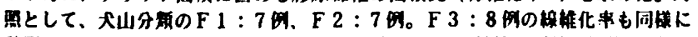

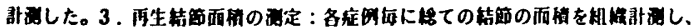

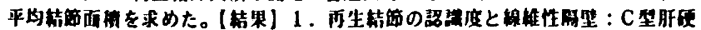

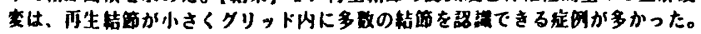

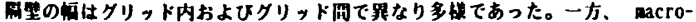

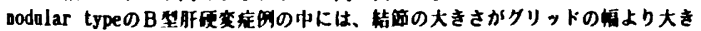

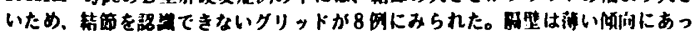

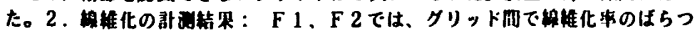

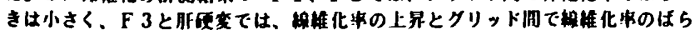

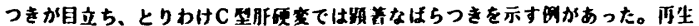

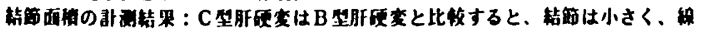

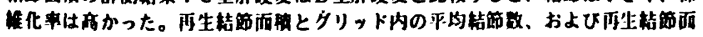

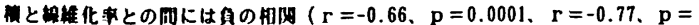

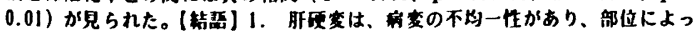

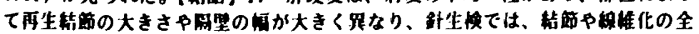

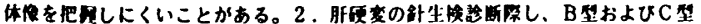

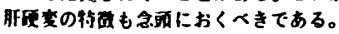

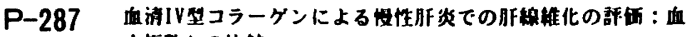 \\ 小板政との比校 \\ 鳥收大学 医学部 第二内科

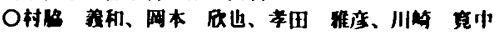

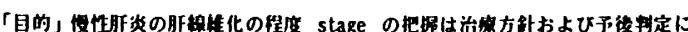

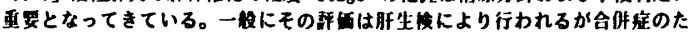

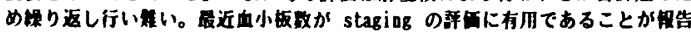

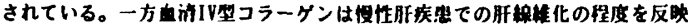

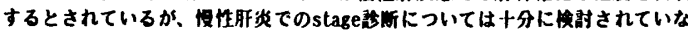

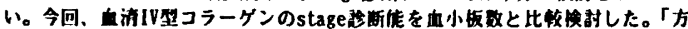

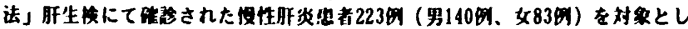

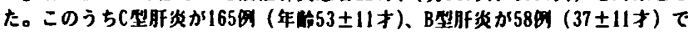

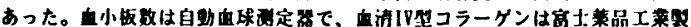

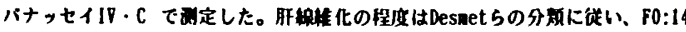

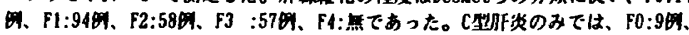

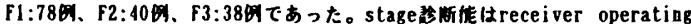

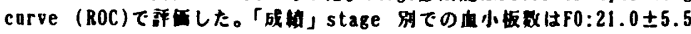
x104/ma3、F1:18.5 $\pm 4.5 、 F 2: 15.7 \pm 4.9 、 F 3: 13.3 \pm 4.5$ (Rruskal-Wallis,

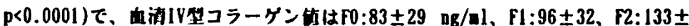

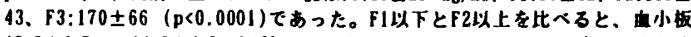

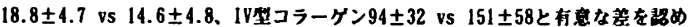

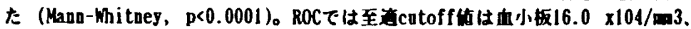

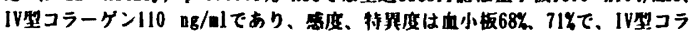

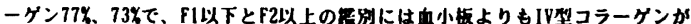
より有用であった。F2以下と下3を比くると、血小板 $17.7 \pm 5.0$ vs $13.4 \pm 4.5$ 、

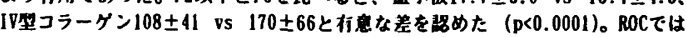

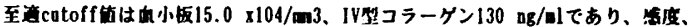
特異度は血小坂67\%、70\%て、、IV型コラーダン68\%、76\%で、F2以下とF3の跑能

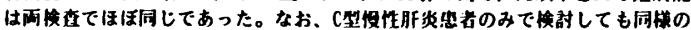

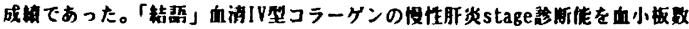

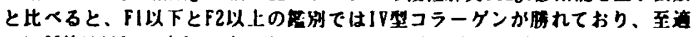

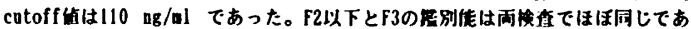

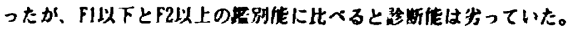

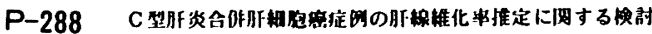

厷岛大学 医学部第二外科

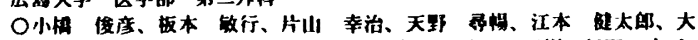

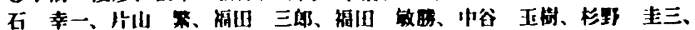
丸林渴二、温原利正

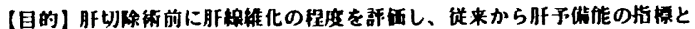
されているICGR

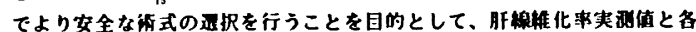

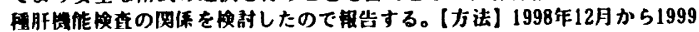

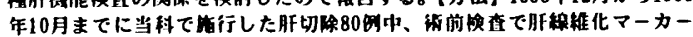

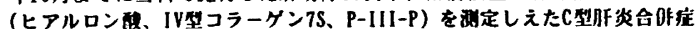

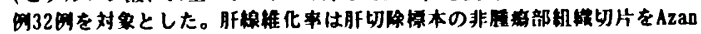

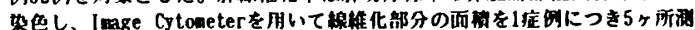

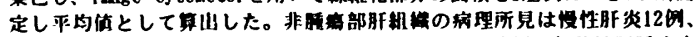

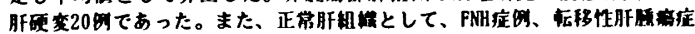

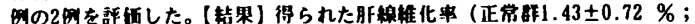

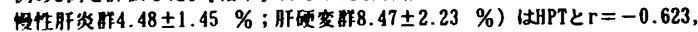

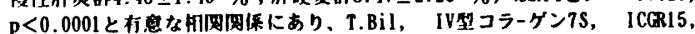
BTRもそ九そ九r=0.609, $p<0.0001 ; r=0.529, \quad p=0.0011 ; r=$ $0.526, p=0.0011 ; r=-0.468, p=0.0047$ と存意な㕲网を示した。そ

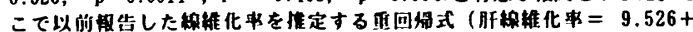
$0.174 \times \mathrm{BTR}+2.875 \times \mathrm{T} . \mathrm{Bil}-0.12 \times \mathrm{HPT}+0.003 \times$ ヒアルロン +0.473× IV 型コラーダン7S) に当てはめると、 $\mathrm{r}=0.802, \mathrm{p}<0.0001$ であった。尚、尀

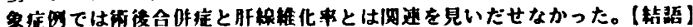

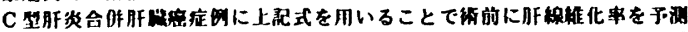

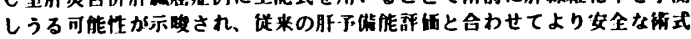
通択に们用であると䒚えた。 


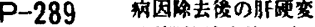

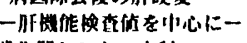

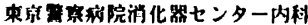

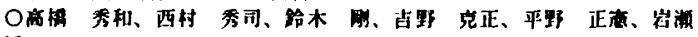 \\ 通
}

目的：近作算入のインターフェロン(IFN)により、C型胙硬変のウイルス排

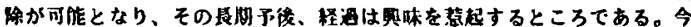

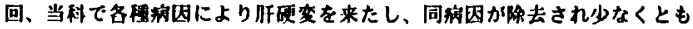

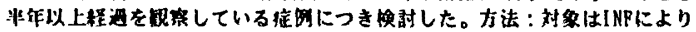

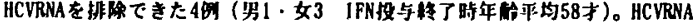

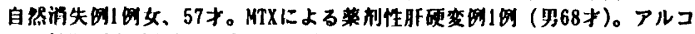

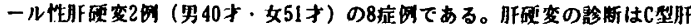

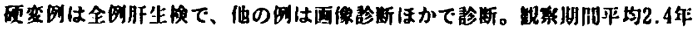
(0.5から4年)。被因除去後 $3 、 6 、 12 、 18 、 24 、 36 、 48 r$ 月時点でのPIt、

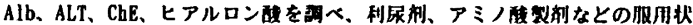

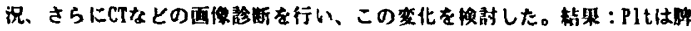

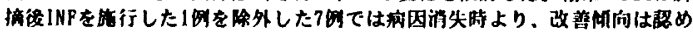

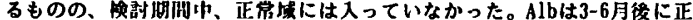

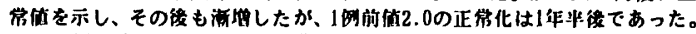

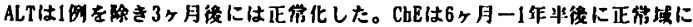

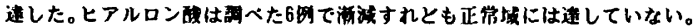

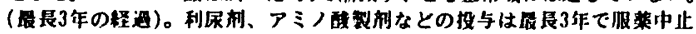

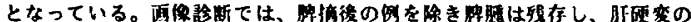

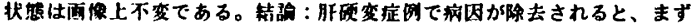

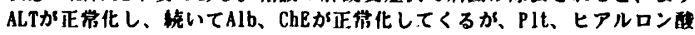

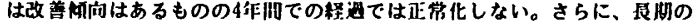
铋察が必要である。

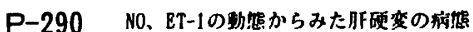

岩手医科大学第 1 内科

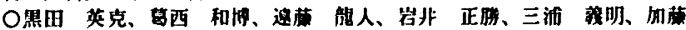
盖信、鉿木一幸

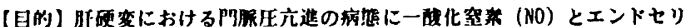

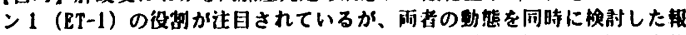

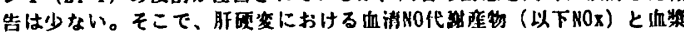

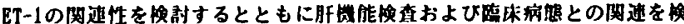

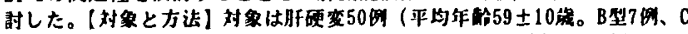

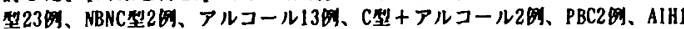

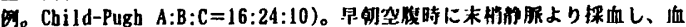

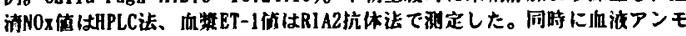

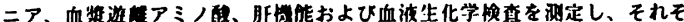

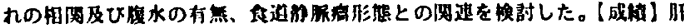

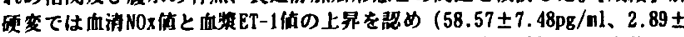

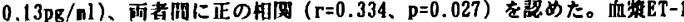
份はChildCではChildA、Bより有意 $(p<0.05)$ に市く、T-Bil、BUNと有意

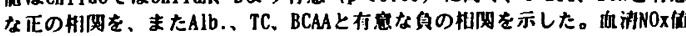

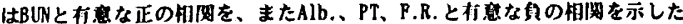

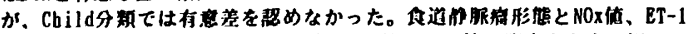

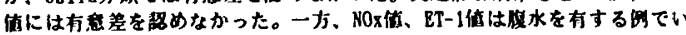

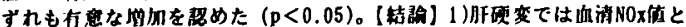

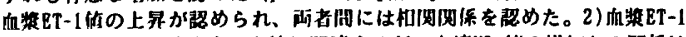

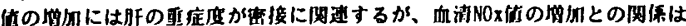
明らかではなかった。

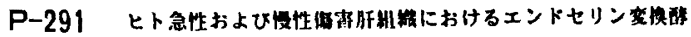
*の荤㽙について

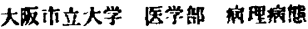

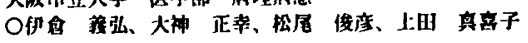

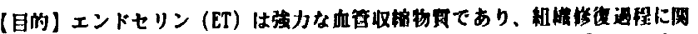

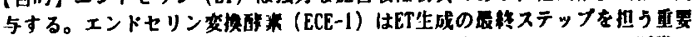

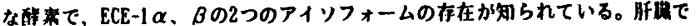

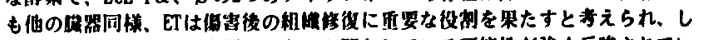

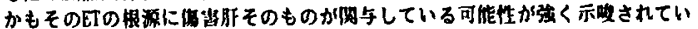

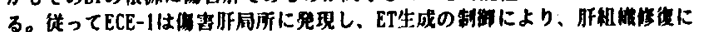

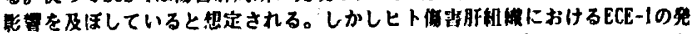

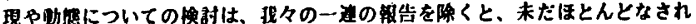

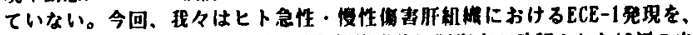

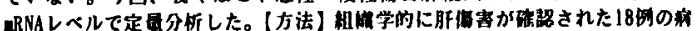

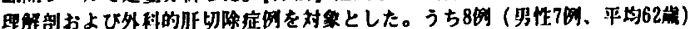

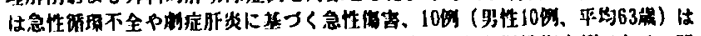

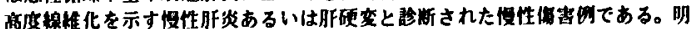

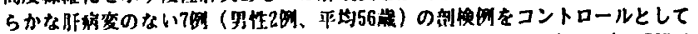

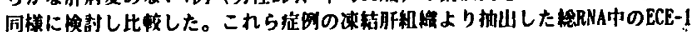
およひ各アイソフォームのARNA発现最を、PCR定是分析法 (ABI 7700、PEハイ

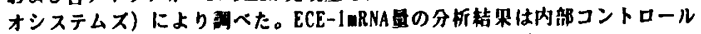

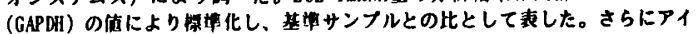
ソフォームについては、基萧サンブルでの相祄值をもとに、各サンプルことの

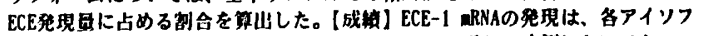

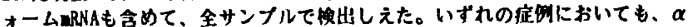

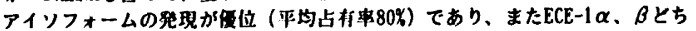

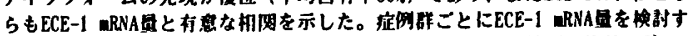

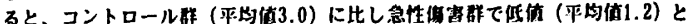

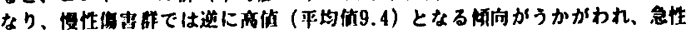

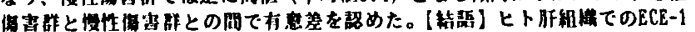

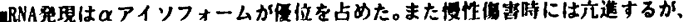

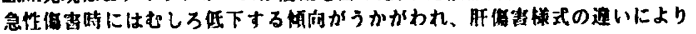

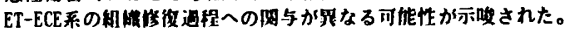

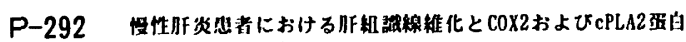

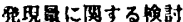

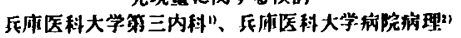

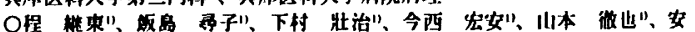

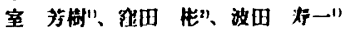

(日的) COX2 (cyclooxgenase 2) とcPLA2 (cytosolic phospholipaseA2)

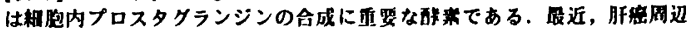

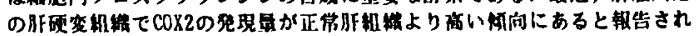

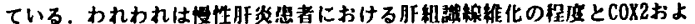

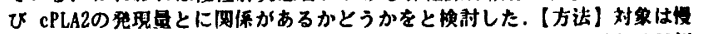

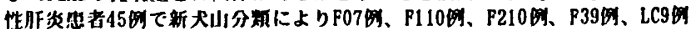

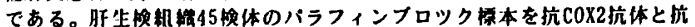

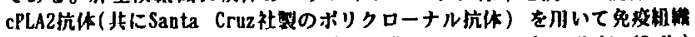

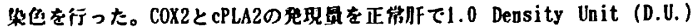

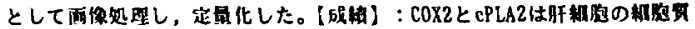

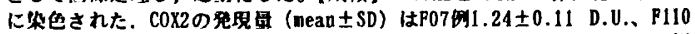

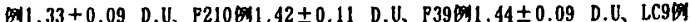

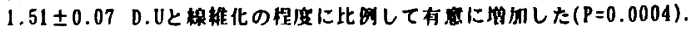

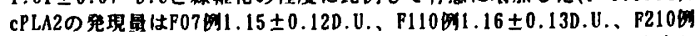

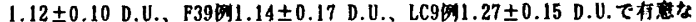

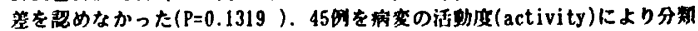

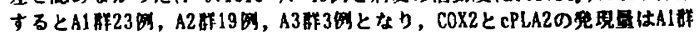

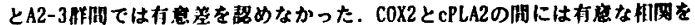

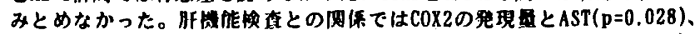
$\operatorname{ALT}(p=0.042) 、 \operatorname{ZTT}(p=0.002) 、 r-g l o b(p=0.006) 、 A l b(p=0.0002)$.

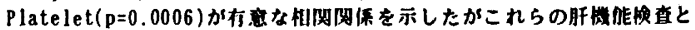

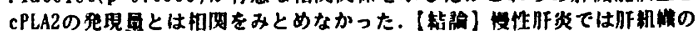

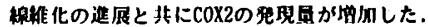




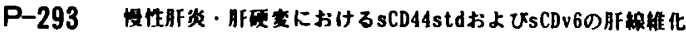

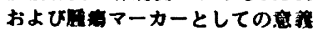

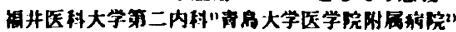

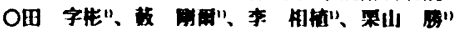

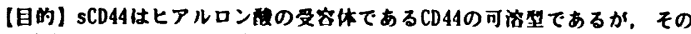

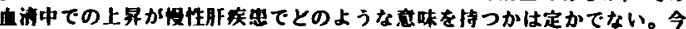
回、sCD44のレヘルと胙の維化マーカーとくに血消ヒアルロン碳のレヘル

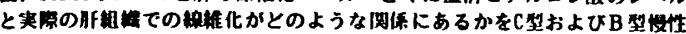

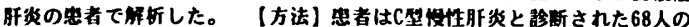

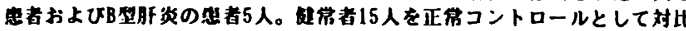

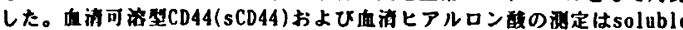
CD44 standard formおよび6を涩定するEIAキット(one-step sandwich BIA, Tyugai Co.) で消定された。ヒアルロン酸はBIAキット(one-step

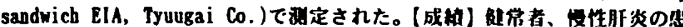

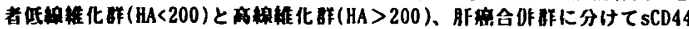

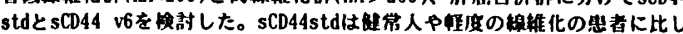

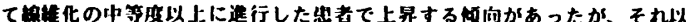

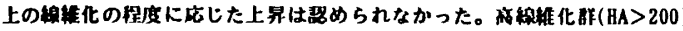

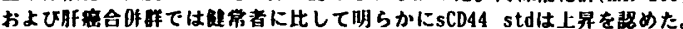

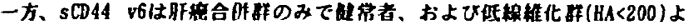

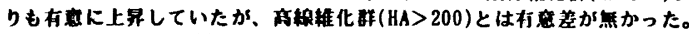

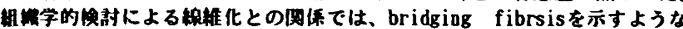

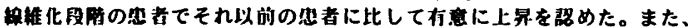

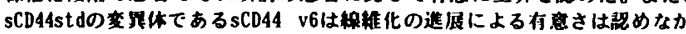

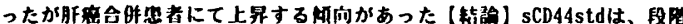

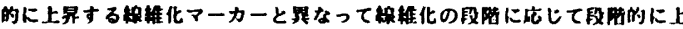

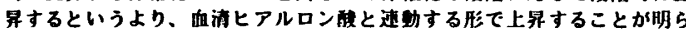
かになった。このことは、sCD44stdかヒアルロン戌の血怆へルに乩して

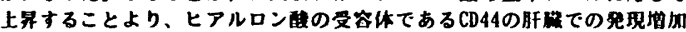

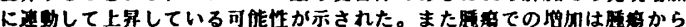

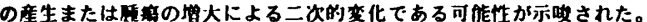

\author{
P-294 侵胙疾におけるとトロネクチンとマトリックスメタロフ \\ ロテアーゼの闾通

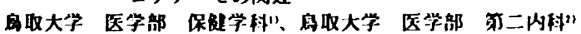

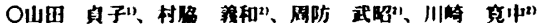

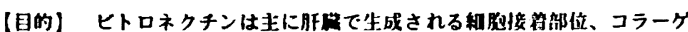

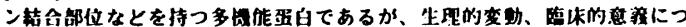

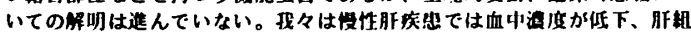

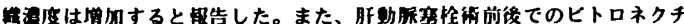

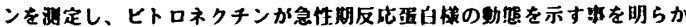
にした。一方、ヒトロネクチンの分㧱については明らかでないか、最䜣 ヒトロネクチンがマリックスメタロプロテアーセ (MMPs) で分解される

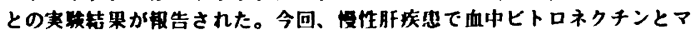
トリックスメタロプロテアーセの网娇を锥するとともにヒトロネクチン

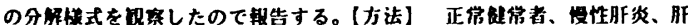

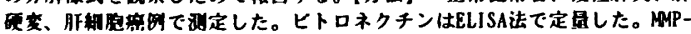

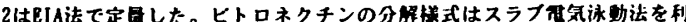

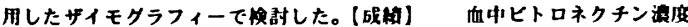

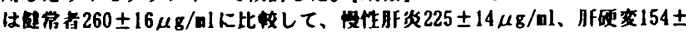

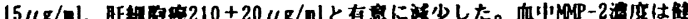

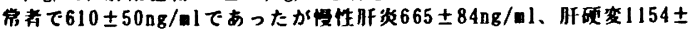

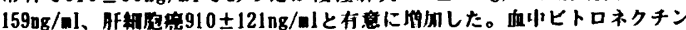

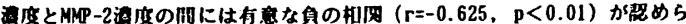

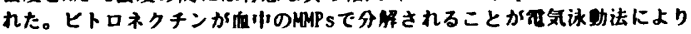

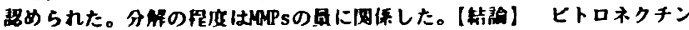

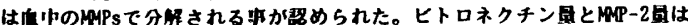

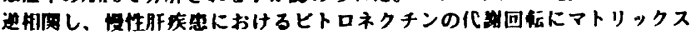
メタロプロテアーセの网与が倠定された。
P-295 LECラットにおける小柴胡识、リコヘンの䛲椎化坜制奻果 に圆する锁討

香川医科大学 医学部 可三内枓

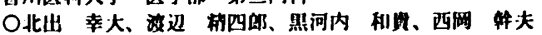

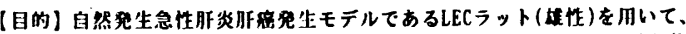

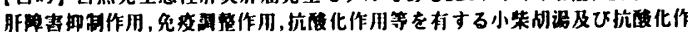

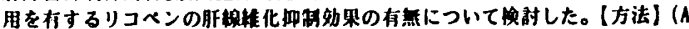

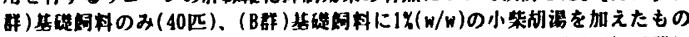

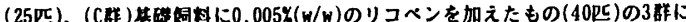

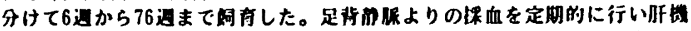

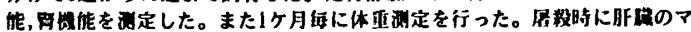

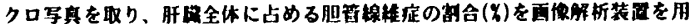

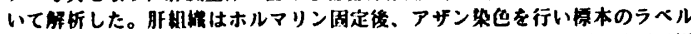

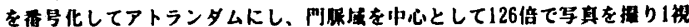

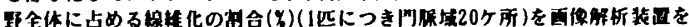

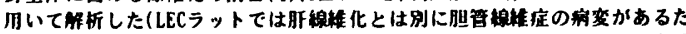
め、今回の方法にしたり。また伊來相的の活件を見るために一切片全体に占め

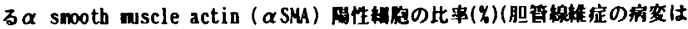

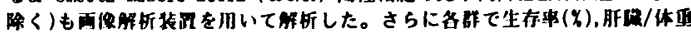

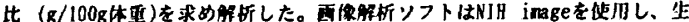

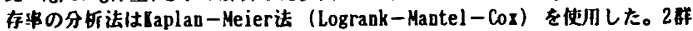

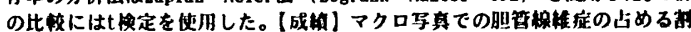

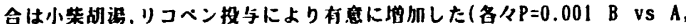

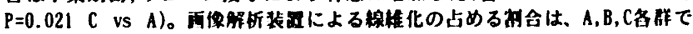
$1.35 \pm 0.56,0.72 \pm 0.34(P=0.0004 B$ vs $A), 0.78 \pm 0.75(P=0.0102 C$ vs A)と萊制投与作では、コントロール群と比して有息に楾椎化が师物されてい

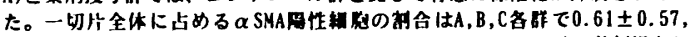
$0.11+0.05(P=0.0131$ B vs $A), 0.12 \pm 0.06(P=0.0153 C$ vs $A)$ で萊制投与に

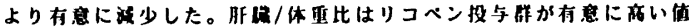

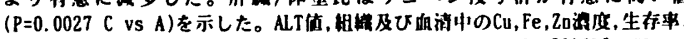

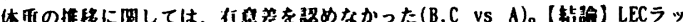

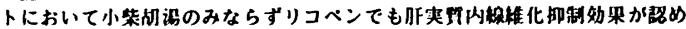

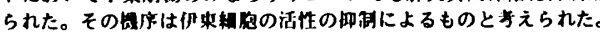

P-296 阅節リウマチにおける血济楾椎化マーカー：メソトレキセー ト投与の跎每

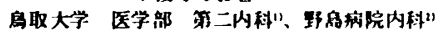

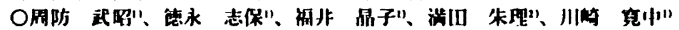

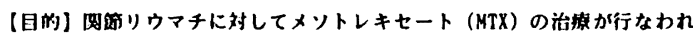
るようになった。しかし、MTXはALTの上界がなくても朋緗椎症队胙硬変が

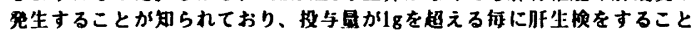

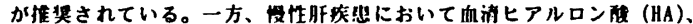
III梨プロコラーダンヘプチト (PIIINP)、IV型コラーダン・7Sトメイン

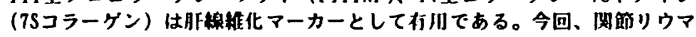

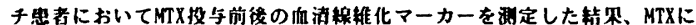

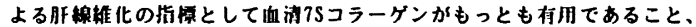

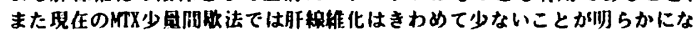

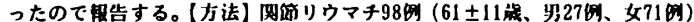

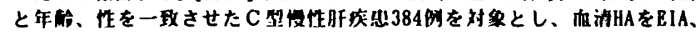

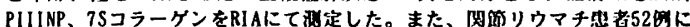

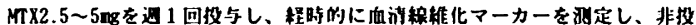

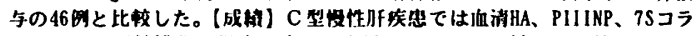

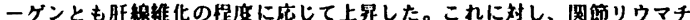

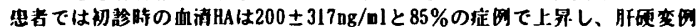

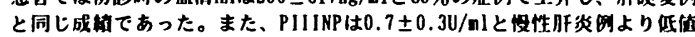
であったが、27\%の底国で罪かみられた。しかし、7Sコラーグンは4.2士

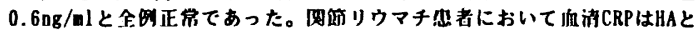

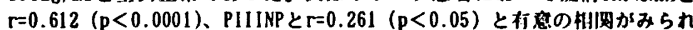

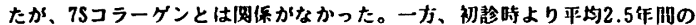

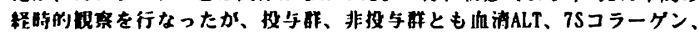

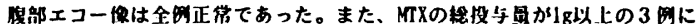

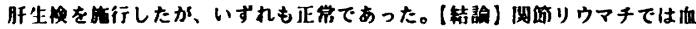

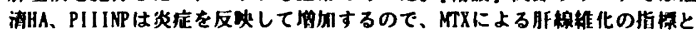
して血清7Sコラーグンがもっとも有用と考えられた。また、現在用いられ

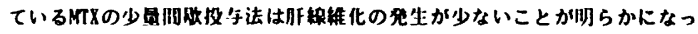
た。 

累-

岁手医科大学医学部第一内科

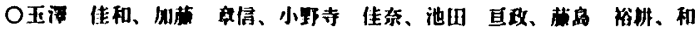

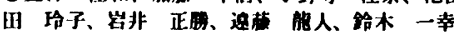

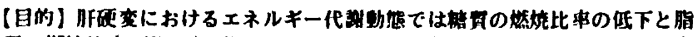

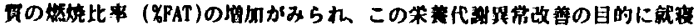

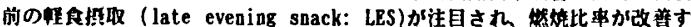

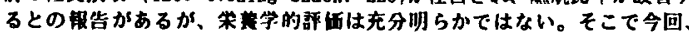

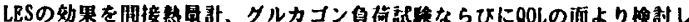

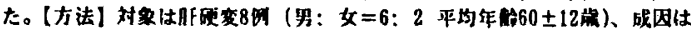

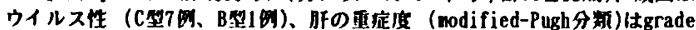

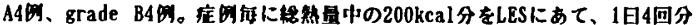

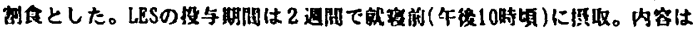

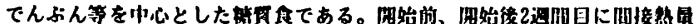

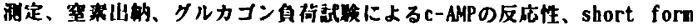

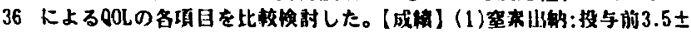

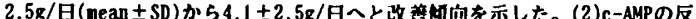

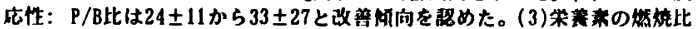

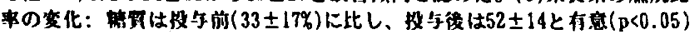

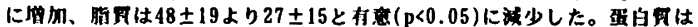
$19 \pm 8$ か $20 \pm 5$ と不交であった。促ってnpRQは $0.7 \pm 0.05 よ り 0.85 \pm 0.06$ と

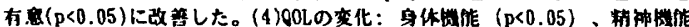

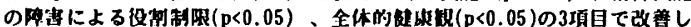

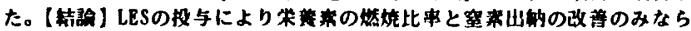

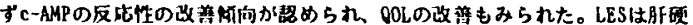

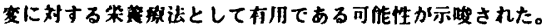

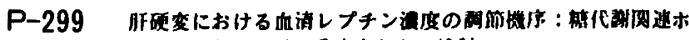

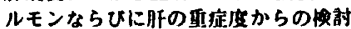

岩手医科大学 医学部 第一内科

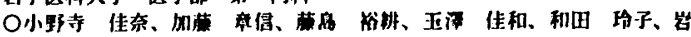

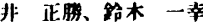

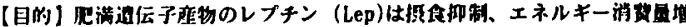

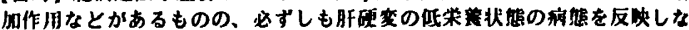

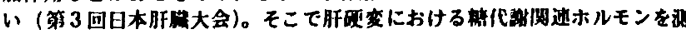

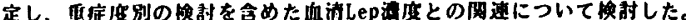

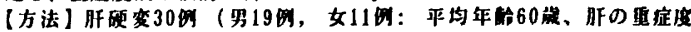
(modified-Pugh): gradeA 14M, gradeB 12\%, gradeC 4)に)にいて早朝

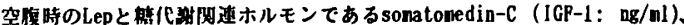
insulin-like growth factor-binding protein-3 (IGPBP-3: $\mu \mathrm{g} / \mathrm{nl}$ )を汹定

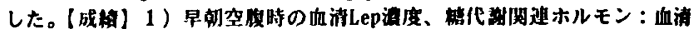

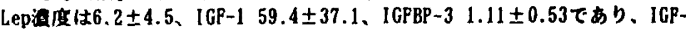
1、IGFBP-3とも继常者に比し落明に低值 $(p<0.001)$ であった。2) 重症度

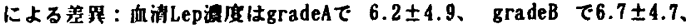
gradeCて 4.6さ2.9とgradeCで低下初向がみられた。IGP-1はgradeA 78.1士

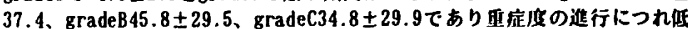
下留向が見られた。同様にIGPBP-3もgradeAで $1.4 \pm 0.4$. gradeB $1.0 \pm 0.5$ 、 gradeC $0.5 \pm 0.2$ と重症度の造行に伴い低下しgradeAとCでは有意（ $p<$

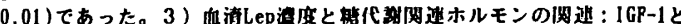

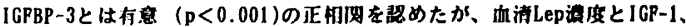

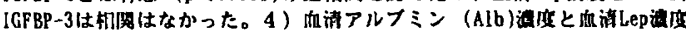

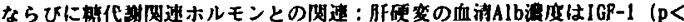

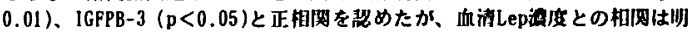

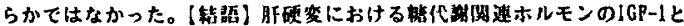

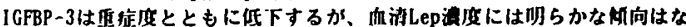
い。また朋の任症度の灲定因子である血清Alb港度もIGP-1、IGPPB-3とは相

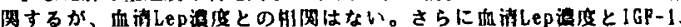

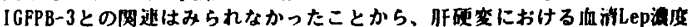

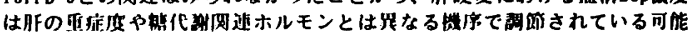
吽が示惨される。

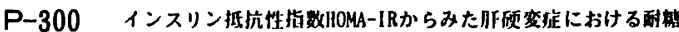 能期营}

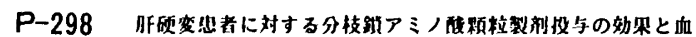
中エンドトキシン

奈良然立医科大学 射三内科

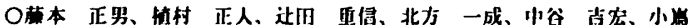

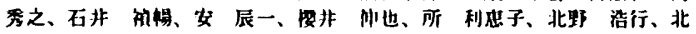

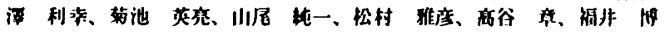

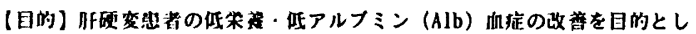

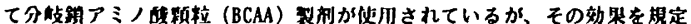

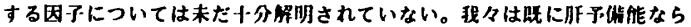

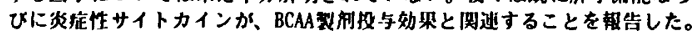

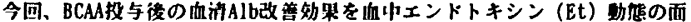

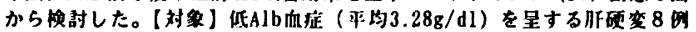

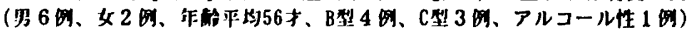
であり、Child-Pughスコアは 6 10点 (平为8.6点) である。(方法) BCAA

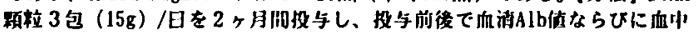
Et 泣度を测定した。Etは理んのPCA改良法により合成基留エンドスベーシー

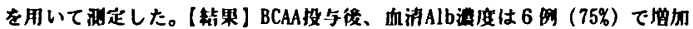
$(3.15 \rightarrow 3.67 \mathrm{~g} / \mathrm{dl})$ ᄂ、 2 (25\%) T低下 $(3.5 \rightarrow 3.3 \mathrm{~g} / \mathrm{dl}, 3.8 \rightarrow 3.4 \mathrm{~g} / \mathrm{dl})$

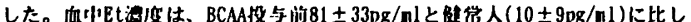

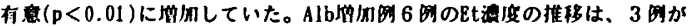

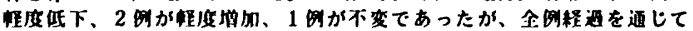

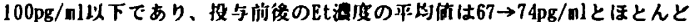

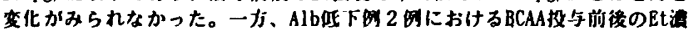

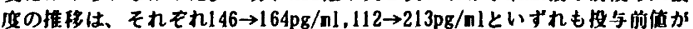

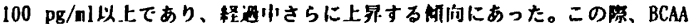

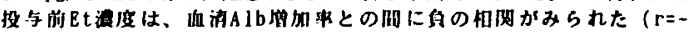

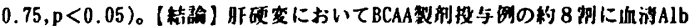

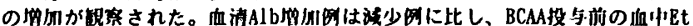

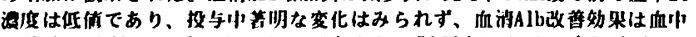

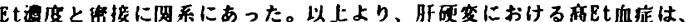

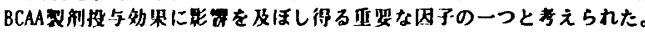

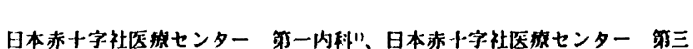
内科"、日本赤十字补际旗七ンター 第一湖化器科”

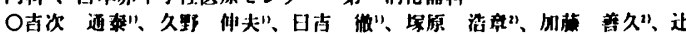

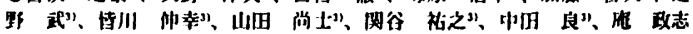

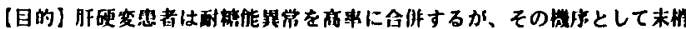

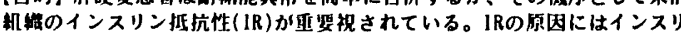

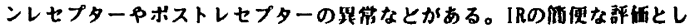
てMatthewsらにより捉鸺されたlloneostas is model assessnent(HOMA-IRと

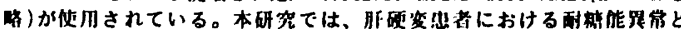

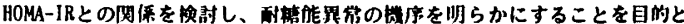

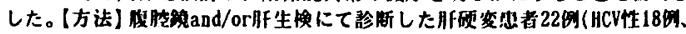

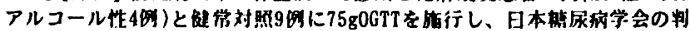

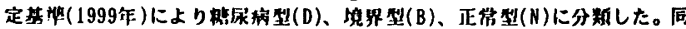

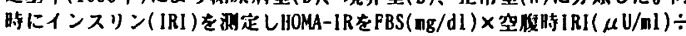

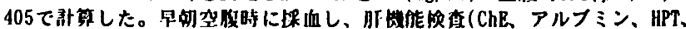

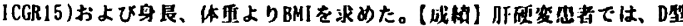

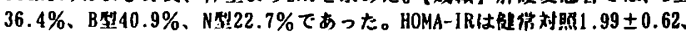

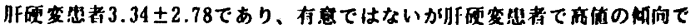

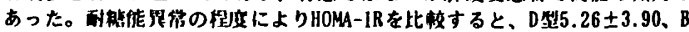

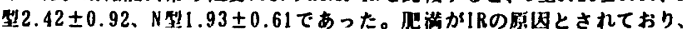
BMI別に比枚した。BMIく24ではD型25.0\%、B犁58.3\%、N型16.7\%、BMI

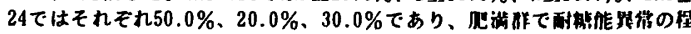

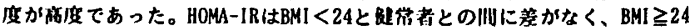

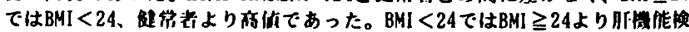

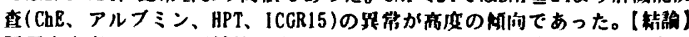

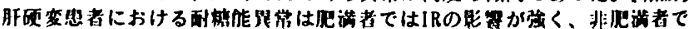

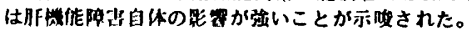


P-301

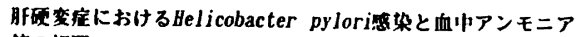
估の相闺

四和大学 医学部 第二队科

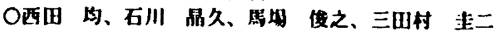

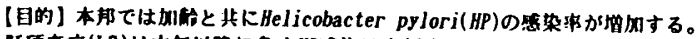

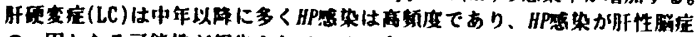

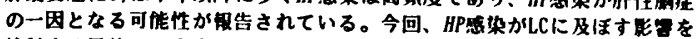

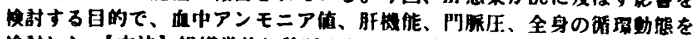

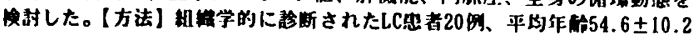

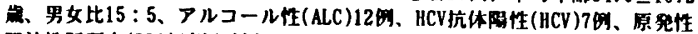

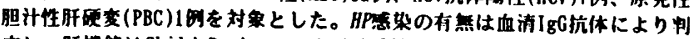

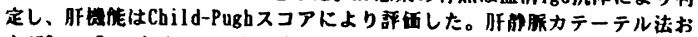

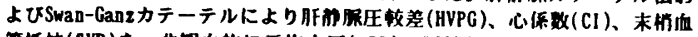

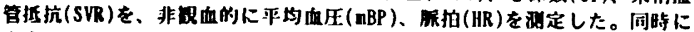
中中アンモニアおよひPisher比を测定した。本研究は昭和大学医学部侮理

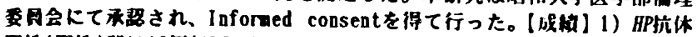

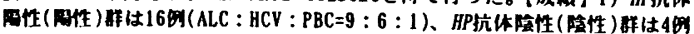

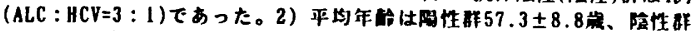

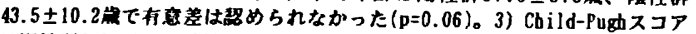

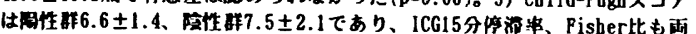

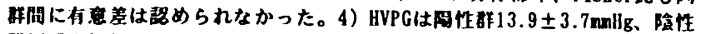

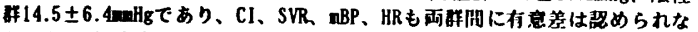

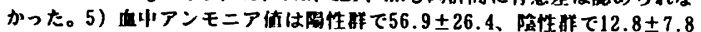

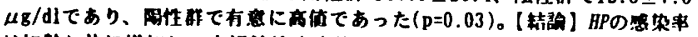

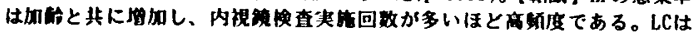

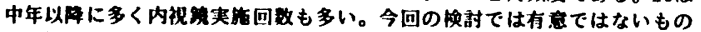

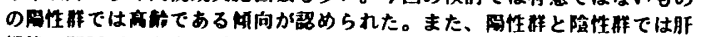

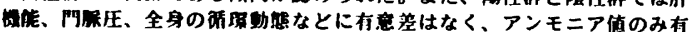

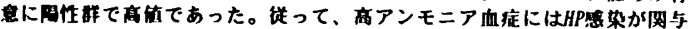

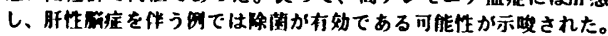

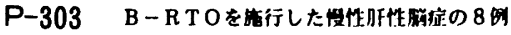

日本医科大学 第一内科

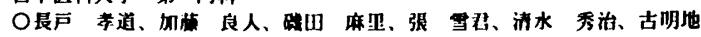

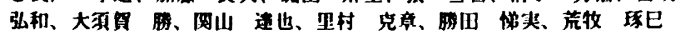

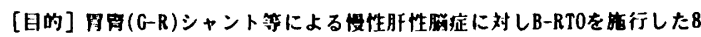

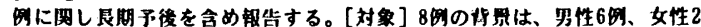

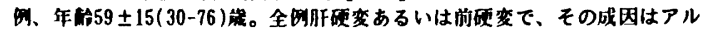

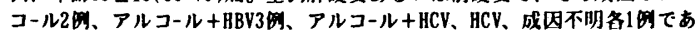

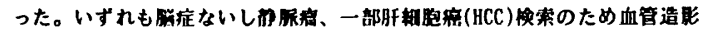

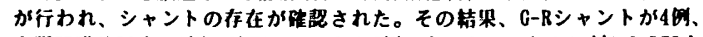

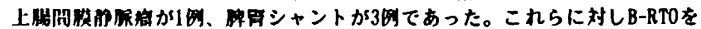
行った。なお、19においてB-RTO值行以弟にHCCに対しTAEかなされていた。

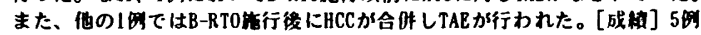
では1回のB-RTOによりシャントの阴寒が得られた。しかし、19474炭、女 性)では巨大シャントのため3回の非行にもかかからず間瑟は得られず、ま た、また、他の1成(65䁾、男性)では2回の手技により閣塞が得ら九た。以

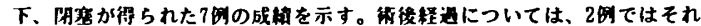

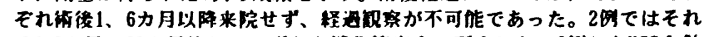
それ9カ月、30カ月媵に、いずれも洞化出血で死亡した。2

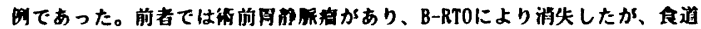

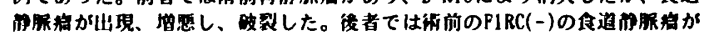

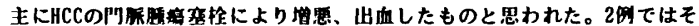

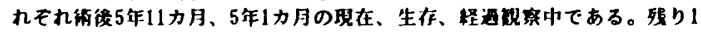

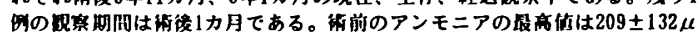
$g / d l(n=7,128-500), 1$ 迥啳 $51 \pm 30(n=6) 、 1$ 力月後 $41 \pm 18(n=5) 、 6$ 力月後 $54 \pm 9(\mathrm{n}=4) 、 12$ 力月啳 $43 \pm 20(\mathrm{n}=3), 2$ 年以上追跡できだでもアンモ二

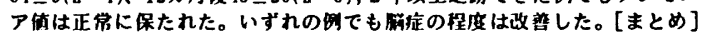

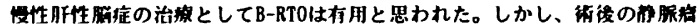

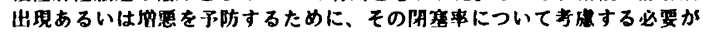
あると思われた。

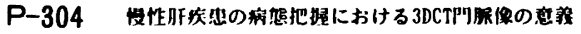

広島大学 医学部 第一内科

○松本朋子、北本輅也、相方浩、地四治、川上由有、大石

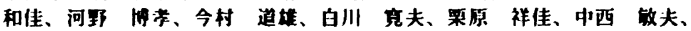
纪山梧㓛

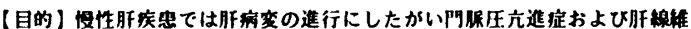

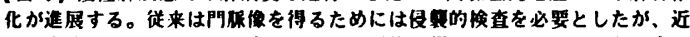
年は商速へリカルCTにより容易に3DCT阿像が得られるようになった。今

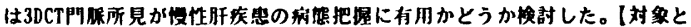

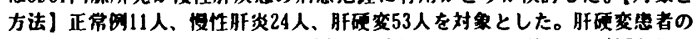

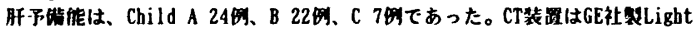

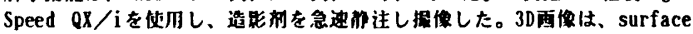

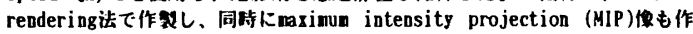

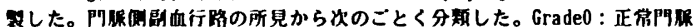

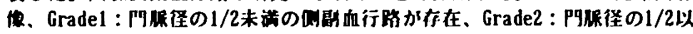

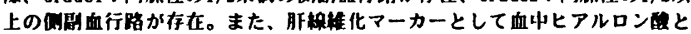

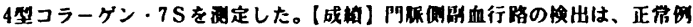

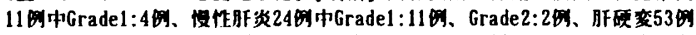

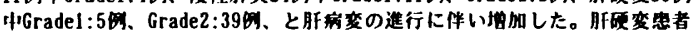

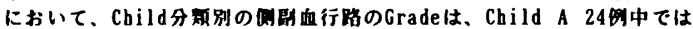

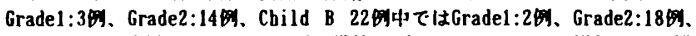

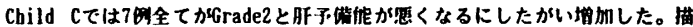

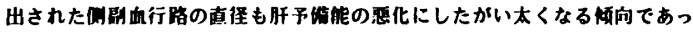

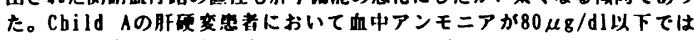
Grade2の比串は44\% (7/16) であり、一方81 $\mu \mathrm{g} / \mathrm{dl}$ 以上ではGrade2の比事は

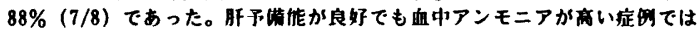

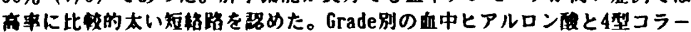
グン・7Sの平均估はそれぞ Gradel:284.0 ng/ml、7.32 ng/ml. Grade2:468.8 ng/ml, $8.91 \mathrm{ng} / \mathrm{ml}$ と

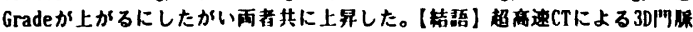

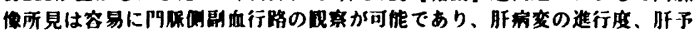

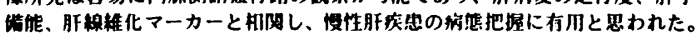




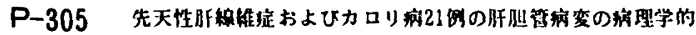
饮矿

金沢大学 医学部 第 2 的理

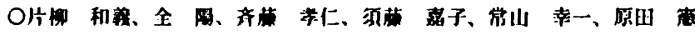
一、中沼 安二

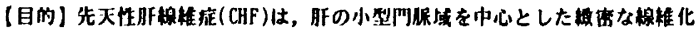

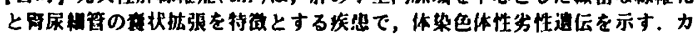

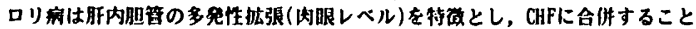

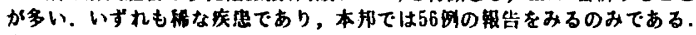

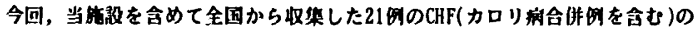

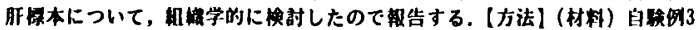

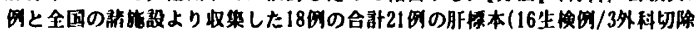

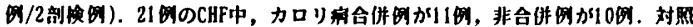

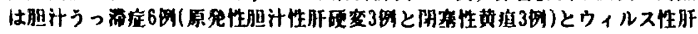

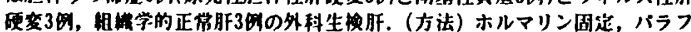

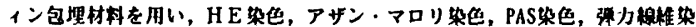

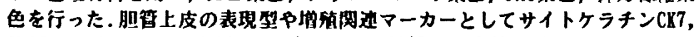

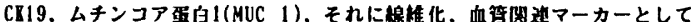

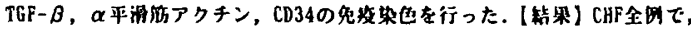

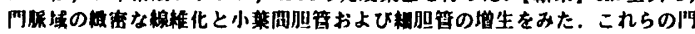

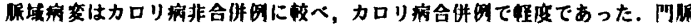

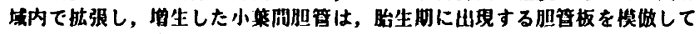

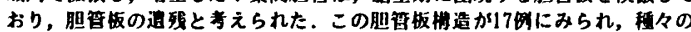

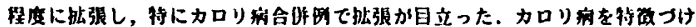

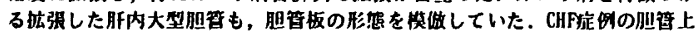

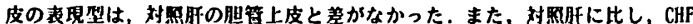

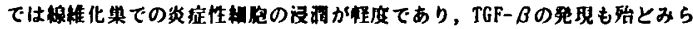

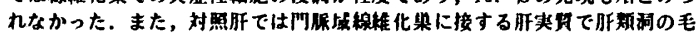

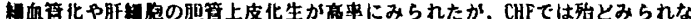

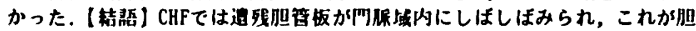

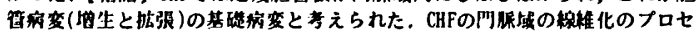
スは他の慢怍疢㷛のプロセスとは界なることが示唆された。

\section{P-306 Sclerosing cholangitisの像を旺したトロトラスト沈㯫の 一个}

带広第一料院 内科

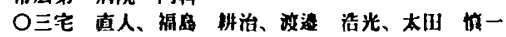

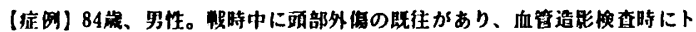

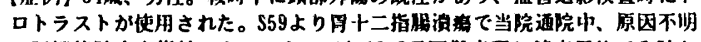

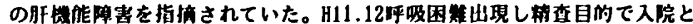

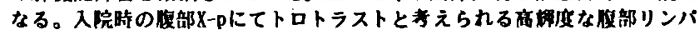

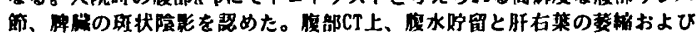

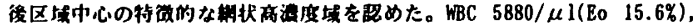
PIt 21 万/ $\mu 1, \mathrm{~T}$-bil $1.7 \mathrm{ng} / \mathrm{dl}$, COT $52 \mathrm{~V} / \mathrm{l}$, GPT $42 \mathrm{U} / \mathrm{l}$, ALP 1270 U/l, $\gamma$-GTP $169 \mathrm{U} / \mathrm{l}$, Alb $2.4 \mathrm{~g} / \mathrm{dl}$, CRP 2.3ng/dl, HBs Ag 陵性, HCV Ab 除性, AFP $1.4 \mathrm{ng} / \mathrm{ml}$, PIVTA-II $343 \mathrm{U} / \mathrm{nl}$, CEA $5.0 \mathrm{ng} / \mathrm{ml}$, CAl9-9 48.5

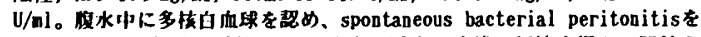

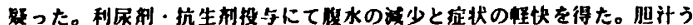

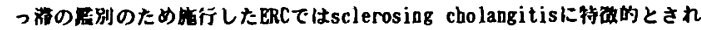
る朋内胆管のbeaded appearance, annular strictureが認められた。また

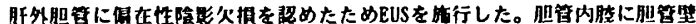

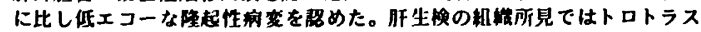

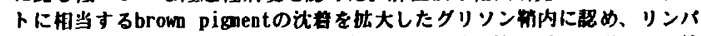

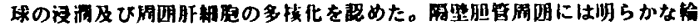

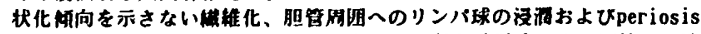

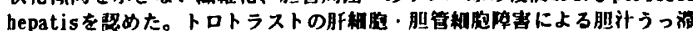

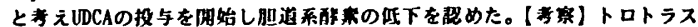

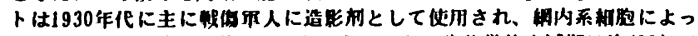

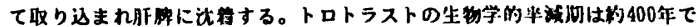

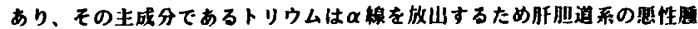

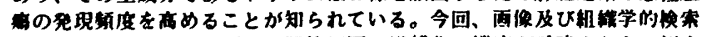

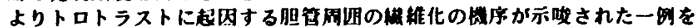
経械したので段皆した。 